\title{
Dışa Açıklık ile İşsizlik Arasındaki İlişki: Seçilmiş AB Ülkeleri ve Türkiye Üzerine Zamana Göre Değişen Parametreli Bir Analiz'
}

\author{
Ramazan EKİNCI, Department of Economics, Faculty of Economics and Administrative Sciences, Dokuz Eylul \\ University, Turkey; e-mail: ramazan.ekinci@deu.edu.tr
}

Osman TÜZÜN, Department of Economics, Faculty of Economics and Administrative Sciences, Dokuz Eylul University, Turkey; e-mail: osman.tuzun@deu.edu.tr

Fatih CEYLAN, Department of Economics, Faculty of Economics and Administrative Sciences, Dokuz Eylul University, Turkey; e-mail: fatih.ceylan@deu.edu.tr

Hakan KAHYAOĞLU, Department of Economics, Faculty of Economics and Administrative Sciences, Dokuz Eylul University, Turkey; e-mail: hakan.kahyaoglu@deu.edu.tr

\section{The Relationship between Openness and Unemployment: A Time Varying Parameter Analysis on Selected EU Countries and Turkey ${ }^{2}$}

\begin{abstract}
Spreading the shocks to economies appears from two channels with the globalization process. These channels are the transmission channels of trade and finance. These two mechanisms generated effects simultaneously on economies after the 2007-2008 global crisis. Simultaneous effects started a process emerging as a decline in economic growth and an increase in the unemployment rate. Generally, the measures taken against these process have been implemented as monetary expansion (Quantative easing-QE) policies, however the countries, which particularly EU countries that not carrying out common fiscal policy, fall into liquidity trap in the sense that the effects of as mentioned policies usually expose to a time varying unemployment process. Therefore, in this study by using a time varying parameter techniques the responses of the unemployment rates to openness levels have analyzed. In the periods of 2011Q1-2015Q4 by using a time varying parameter VAR (TVP-VAR) method developed by Nakajima (2011), what extent the unemployment rates are affected from the openness level of the countries is analyzed. According to the findings of the study, it has found that the openness level of the countries in question has a decisive feature on unemployment. It has also revealed that the UK is economically different from the EU, and the effects of openness on unemployment for France and Germany are asymmetrical.
\end{abstract}

Keywords : : Openness Rate, Unemployment Rate, TVP-VAR.

I Bu çalışma Aydın'da düzenlenen EUREFE-2016 konferansında sunulmuş ve yapılan katkalarla yeniden gözden geçirilmiştir.

2 This paper was presented at the EUREFE-2016 conference held in Aydin and was reviewed by the current contributions. 
JEL Classification Codes : $\quad$ C32, E23, F41.

\section{Öz}

Küreselleşme süreciyle birlikte ülke ekonomilerine şokların yayılması iki kanaldan ortaya çıkmaktadır. Bu kanallar ticaret ve finansal kanallar aktarım kanallarıdır. 2007-2008 Küresel krizi sonrasında bu iki mekanizma eş anlı olarak ülke ekonomileri üzerinde etkiler ortaya çıkarmıştır. Eş anlı etkiler ekonomik büyümede düşüş, işsizlik oranlarında artış şeklinde ortaya çıkan süreci başlatmıştır. Buna karşı alınan önlemler genel olarak parasal genişleme (quantitative easing-QE) politikaları olmuştur ancak ülkelerin likidite tuzağına (liquidity trap) düşmeleri özellikle AB gibi ortak bir maliye politikası uygulama imkânının olmadığı bir yapıda söz konusu politikaların etkisini genel olarak zamana göre değişen bir işsizlik süreciyle karşı karşıya bırakmaktadır. Bundan dolayı bu çalışmada zamana göre değişen parametreli tekniklerle dışa açıklık düzeylerine karşı işsizlik oranlarının verdiği tepkiler analiz edilmiştir. 2001Q1-2015Q4 döneminde işsizlik oranlarının ülkelerinin dışa açıklık düzeylerinden ne derece etkilendiği Nakajima (2011) tarafından geliştirilen ve parametrelerin zamana göre değişkenliğini dikkate alan "Zamana Göre Değişen Parametreli VAR (TVP-VAR)" yaklaşımı çerçevesinde analiz edilmiştir. Bu çalışmanın bulgularına göre; ele alınan ülkelerde dışa açıklığın işsizlik üzerinde belirleyici bir özelliğe sahip olduğu sonucuna ulaşılmıştır. Ayrıca İngiltere'nin ekonomik açıdan AB'den farklılaştığı, Fransa ve Almanya'da ise dışa açıklığın işsizlik üzerindeki asimetrik etkileri ortaya konmuştur.

\section{Anahtar Sözcükler : Dişa Açıklık Oranı, İsssizlik Oranı, TVP-VAR.}

\section{Giriş}

Dünya ekonomisinde küreselleşme süreci ile birlikte ortaya çıkan etkiler finansal ve reel değişkenlere bağlı olarak bir yayılma göstermektedir. Bu değişkenler ayrıca birer aktarım kanalı olarak ifade edilmektedir. Söz konusu etkilerin neden olduğu şokların ülke ekonomileri üzerindeki etkisi farklı olabilmektedir. Bu etkilerin farklılığı ülke ekonomileri arasında farklı olmasının nedeni, ülkelerin ekonomik yapılarına bağlı olarak değişkenler arasındaki esnekliklerin farklı olmasıdır. Bu farklılaşma aynı zamanda dışarıdan kaynaklanan şokların ülkelere yayılma hızının veya etki derecesinin değişmesine yol açmaktadır. Ayrıca her bir zaman döneminde söz konusu parametrelerin değişmesi, değişkenler arasında da ilişkilerin değişimine neden olur. Bundan dolayı özellikle küreselleşen dünyada ülkelerin arasındaki ekonomik etkiler farklılaşır. Bu açıdan dışa açık ekonomiler üzerinde yapılacak analizlerde zaman göre parametre değişimleri, iktisat teorilerinin değerlendirilmesinde bilgiler sunmaktadır.

2007-2008 Küresel krizi sonrasında bu süreç eş anlı olarak ülke ekonomileri üzerinde etkiler ortaya çıkarmıştır. Eş anlı etkiler ekonomik büyümede düşüş, işsizlik oranlarında artış şeklinde ortaya çıkan süreci başlatmıştır. Buna karşı alınan önlemler genel olarak parasal genişleme (quantitative easing-QE) politikaları olmuştur ancak ülkelerin likidite tuzağına (liquidity trap) düşmeleri özellikle $\mathrm{AB}$ gibi ortak bir maliye politikası uygulama imkânının olmadığı bir yapıda söz konusu politikaların etkisini genel olarak zamana göre değişen bir işsizlik süreciyle karşı karşıya bırakmaktadır.

Bu çalışmada; dış ticaret hacminin milli gelir içindeki payı olan ticari dışa açıklık oranı ile ülkelerin işsizlik oranları üzerinde zaman içinde ne gibi etkiler meydana getirdiği 
analiz edilmektedir. İlerleyen kısımda dışa açıklık oranı ile işsizlik oranı arasındaki ilişkiye dair seçilmiş literatüre değinilmiştir. Üçüncü kısımda AB ve Türkiye'de söz konusu ilişki zamana bağlı değişen ampirik bulgulara ve son kısımda ise sonuç ve öneriler gösterilmiştir.

\section{Literatür}

İktisat teorisinde ticari serbestleşmenin etkisi modern dış ticaret teorisinin temelini oluşturan Heckscher-Ohlin teoremine göre yapılmaktadır (Acar, 2012: 126). Bu teorik yaklaşım klasik karşılaştırmalı üstünlükler teorisine dayalı olduğu için, hem uzun dönemli bir analiz hem de parametrelerin değişmezliği sonucunu ortaya çıkarmaktadır. Ancak ülkelerin ekonomik yapılarının, ekonomik değişkenlerin şoklara karşı duyarlılığının, uzun ve kısa dönem esnekliklerin farklı olması zamana göre parametrelerin de değişmesine yol açmaktadır. Bununla birlikte ekonomide fiyatların aşağıya ve yukarıya doğru elastikiyetinin düşük olması başka bir ifadeyle yapışkan fiyatların geçerli olması ekonomide iktisat politikaları ile şokların etkilerini asimetrik yapmaktadır. Bununla birlikte özellikle dünyada dış ticaretin endüstri içi hatta firma içi haline gelmesi, aksak rekabetin önem kazanması dışa açık bir ekonomide ekonomik değişkenlerin arasındaki ilişkilerin zaman göre değişimine neden olmaktadır. Bunun başka bir ifadesi ekonomik değişkenlerin birbirine karş1 duyarlılığını gösteren parametrelerin zamana göre değişmesidir. İşsizlik olgusu genel olarak iktisat teorisinde Phillips eğrisi yaklaşımı çerçevesinde ele alınmıştır. Bu açıdan konu enflasyon ve işsizlik arasında değiş tokuşa göre incelenmiştir. Ancak literatürde dışa açıklık ile işsizlik arasındaki ilişkiyi analiz eden çok sayıda çalışma da mevcuttur. Dışa açıklık ile işsizlik arasındaki ilişkinin analizi para politikası ya da stratejisi uygulama sonuçlarının asimetrik olup olmayacağının değerlendirilmesinde önemli bir bilgi sunmaktadır.

Dışa açıklık oranı ile işsizlik oranı arasındaki ilişki literatürde genellikle ülkelerin dışa açılmalarının sonucunda emek verimliliğinin değişmesi üzerinden işsizlik oranlarında değişiklikler meydana getirdiğine değinilmiştir (Ocampo \& Taylor, 1998: 1-3). Söz konusu ilişkinin büyüklüğü ve yönü gelişmiş ülkeler ve gelişmekte olan ülkeler arasında ülkelerde farklılaşmaktadır. Doğaldır ki ülkelerin emek piyasalarının yapısal özellikleri de bir öncül teşkil etmektedir. Aşağıdaki tabloda ticari dışa açıklık ile işsizlik oranı arasındaki ilişkiye dair seçilmiş literatür gösterilmektedir:

\begin{tabular}{|c|c|c|c|}
\hline Yazarlar & İncelenen Dönem & Yöntem / Teknik & Sonuç \\
\hline $\begin{array}{l}\text { Sandalcılar \& } \\
\text { Yalman (2012) }\end{array}$ & $1980-2010$ & $\begin{array}{l}\text { Granger ve Hsiao } \\
\text { nedensellik testleri, } \\
\text { Eşbütünleşme }\end{array}$ & Türkiye'de ticari açıklık emek piyasalarını negatif yönde etkilemektedir. \\
\hline Yanıkkaya (2013) & 1980-2009 & Panel (SUR) & $\begin{array}{l}\text { Gelişmiş ve Gelişmekte olan ülkelerde ticaret engellerin işsizlik üzerine } \\
\text { genellikle olumsuz etkileri vardır. Gelişmiş ülkelerde yüksek ticaret hacimleri } \\
\text { sanayi istihdamını olumsuz etkilemektedir. }\end{array}$ \\
\hline Geronazzo (2016) & 1988-1995 & OLS, DID & $\begin{array}{l}\text { Uruguay'da Ticari küreselleşmenin Artması toplam faktör verimliliğini } \\
\text { arttırmaktadır. Ayrıca mavi yakalılar ile beyaz yakalılar arasındaki ücret farkı } \\
\text { azalmaktadır. }\end{array}$ \\
\hline Dutt vd. (2009) & $1985-2005$ & OLS, Panel & Ticari açıklıkla işsizlik oranı arasında negatif ilişki söz konusudur. \\
\hline Hasan vd. (2012) & $\begin{array}{l}1987-1988 \\
1993-1994 \\
1999-2000 \\
2004-2005\end{array}$ & $\begin{array}{l}\text { VECM, Granger } \\
\text { nedensellik }\end{array}$ & Ticari açıklık Hindistan'da kent istihdamını arttırmaktadır. \\
\hline Gozgor (2013) & $1993-2008$ & GMM & $\begin{array}{l}\text { G7 ülkelerinde ticari açıklık istihdamı arttıran bir süreçtir. Ticari açıklıkla işsizlik } \\
\text { oranı arasında negatif ilişki söz konusudur. }\end{array}$ \\
\hline Nwaka vd. (2015) & $1970-2010$ & VECM & Nijerya'da uzun dönemde dışa açıklık işsizlik oranlarını arttırmaktadır. \\
\hline $\operatorname{Kim}(2011)$ & 1961-2008 & OLS & $\begin{array}{l}20 \text { OECD ülkesinde dış ticaretteki artış emek piyasasındaki katılıklara bağlı } \\
\text { olarak toplam işsizliği artırmaktadır. }\end{array}$ \\
\hline
\end{tabular}




\section{Yöntem}

$\mathrm{Bu}$ çalışmada dışa açıklık ile işsizlik arasındaki ilişki Fransa, Almanya, İtalya, İspanya ve İngiltere olmak üzere 5 Avrupa Birliği ülkesi ve Türkiye için test edilmiştir. Çalışmada katsayıların zamana göre değişmediği ve sabit kaldığı varsayımına dayanan klasik VAR yaklaşımına alternatif olarak Zamana Göre Değişen Parametreli VAR (TVPVAR) yaklaşımı kullanılmıştır. Bu çalışmada elde edilen etki tepki analiz sonuçları; ekonomideki yapısal dönüşümler ve krizlerin parametreler üzerindeki etkisiyle birlikte bu parametrelerin zamana göre değişimine izin veren yaklaşımın kullanılmasıyla elde edilmiştir. Böylece kullanılan yöntem etki tepki fonksiyonlarıyla üye ülkelerin dışa açıklık oranlarıyla işsizlik oranları arasında bir asimetri olup olmadığını test etmektedir. Bu yaklaşım şokların ve katsayılara ait varyans-kovaryans matrisinin zamana göre değişimini dikkate almaktadır (Primiceri, 2005: 4). Genel olarak çok değişkenli modellerde gerek bağımsız gerekse bağımlı değişkenin gecikmelerinin kullanılması, uzun zaman aralıkları içinde bağımlılık ilişkisini ortaya çıkarmaktadır. Bu bağımlılık ilişkisi doğrusal olmayan veya zamana göre parametrelerin değişimine yol açan bir süreci ortaya çıkarmaktadır. (Cogley \& Sargent, 2005: 265-266). Böylece parametrelerin zaman içindeki değişimi ile bu değişimin nedenleri ortaya konulabilmektedir. Bu sonuca, parametrelerin tahminine yönelik olarak kullanılan yaklaşım çerçevesinde şokların büyüklüğü veya şiddeti ile değişkenlerin zaman içinde bu şoklara karşı verdiği tepkinin ayrıştırmasıyla ulaşılmaktadır. Bu ayrıştırma tahminleme aşamasında her bir zaman dönemine ait varyans-kovaryans matrisinin değişimine bağlı olarak yapılabilmektedir ( Del Negro \& Primiceri, 2015: 1-2).

Zamana göre değişken parametreli bir VAR yaklaşımının tahmini için ilk olarak aşağıdaki eşitlik kullanılmaktadır (Nakajima, 2011: 109):

$$
y_{t}=c_{t}+B_{1, y_{t-1}}+\ldots \ldots+B_{k, t y_{t-k}}+u_{t} \quad t=1, \ldots \ldots \ldots \ldots ., T
$$

Bu eşitlikte $y_{t}, n \times 1$ boyutlu içsel değişskenler vektörünü; $c_{t}, n \times 1$ boyutlu zamana göre değişken katsayılı sabit terimler vektörünü; $B_{i, t}, i=1, \ldots \ldots \ldots . . . k$ kadar $n \times n$ boyutlu zamana göre değişken katsayılar matrisini ve $u_{t}, \Omega_{t}$ ile gösterilen varyanskovaryans matrisine bağlı olan ve varyansı zamana göre değişen gözlenemeyen şokları ifade etmektedir. $\mathrm{Bu} \Omega_{t}$ varyans-kovaryans matrisinin indirgenmiş diagonal biçimi $A_{t} \Omega_{t} A_{t}^{\prime}=\sum_{t} \sum_{t}^{\prime}$ biçimindedir (Primiceri, 2005: 5-6).

$A_{t}$, alt üçgensel matrisi 


$$
A_{t}=\left[\begin{array}{cccc}
1 & 0 & \cdots & 0 \\
\alpha_{21, t} & 1 & \ddots & \vdots \\
\vdots & \ddots & \ddots & 0 \\
\alpha_{n 1, t} & \cdots & \alpha_{n n-1, t} & 1
\end{array}\right]
$$

ve $\sum_{t}$ köşegen matrisi

$$
\Sigma_{t}=\left[\begin{array}{cccc}
\sigma_{1, t} & 0 & \cdots & 0 \\
0 & \sigma_{2, t} & \ddots & \vdots \\
\vdots & \ddots & \ddots & 0 \\
0 & \cdots & 0 & \sigma_{n, t}
\end{array}\right] .
$$

göstermektedir (Nakajima, 2011). Buradan; diagonal gösterimden yararlanarak 3 numaralı eşitlik elde edilmektedir.

$$
\begin{aligned}
& y_{t}=c_{t}+B_{1, t y_{t-1}}+\ldots \ldots . .+B_{k, t y_{t-k}}+A_{t}^{-1} \sum_{t} \varepsilon_{t} \\
& V\left(\varepsilon_{t}\right)=I_{n}
\end{aligned}
$$

$\mathrm{Bu}$ eşitliğin sağ tarafında yer alan tüm bağımsız değişkenler $B_{t}$ vektörüne dâhil edilirse, elde edilen 3 numaralı eşitlik aşağıdaki gibi yeniden yazılabilir:

$$
\begin{aligned}
& y_{t}=X_{t}^{\prime} B_{t}+A_{t}^{-1} \sum_{t} \varepsilon_{t} \\
& X_{t}^{\prime}=I_{n} \otimes\left[1, y_{t-1}^{\prime}, \ldots \ldots \ldots ., y_{t-k}^{\prime}\right],
\end{aligned}
$$

Burada $\otimes$ sembolü matrislerin kronecker çarpımını göstermektedir (Primiceri, 2005: 5).

Tüm bağımsız değişkenlerin $B_{t}$ vektörüne dâhil edilmesinin nedeni tahmin sürecinde varyans-kovaryans matrisinin ayrıştırılmasının yapılmasını sağlamaktır. Böylece zamana göre değişen VAR yaklaşımında $A_{t}$ matrisinin zamana göre değişmesi ile birlikte $i-t h\left(i^{\prime}\right.$ ninci $)$ değişkenden kaynaklanan bir şokun $j-t h\left(j^{\prime} n i n c i\right)$ değişken üzerindeki etkisinin zamana göre farklılaşıp farklılaşmadığı görülebilmektedir. 
Tahmin aşamasında $a_{t}$ sıfırdan ve birden farklı $A_{t}$ matrisinin sütun elemanlarını; $\sigma_{t}$ ise $\sum_{t}$ matrisinin çapraz(diagonal) elemanlarının vektörünü göstermektedir. Modelin zamana göre değişen parametre yapısı aşağıdaki gibi gösterilebilir (Koop vd., 2009: 999):

$$
\begin{aligned}
& B_{t}=B_{t-1}+v_{t} \\
& a_{t}=a_{t-1}+\zeta_{t} \\
& \log \sigma_{t}=\log \sigma_{t-1}+\eta_{t},
\end{aligned}
$$

Modelde $B_{t}$ vektörünün elemanları rassal yürüyüş süreci izlemekte ve $A_{t}$ matrisi elemanlarından bağımsız olarak ifade edilmektedir. $\sigma_{t}$, standart sapmanın, stokastik oynaklık modellerine benzer geometrik rassal yürüyüş süreci izlediği varsayılmaktadır. $\mathrm{Bu}$ durum TVP-VAR modelinin içerisinde ARCH modelini de barındırdığını göstermektedir. Literatürdeki ARCH modelinden farkı ise yukarıdaki eşitlikteki varyans eşitliğinin gözlenemeyen bileşenlerden oluşması ve burada koşullu varyansın hesaplanamaz olmasıdır (Koop \& Korobilis, 2010). Bu yaklaşımda tüm şokların ortak normal dağılımlı olduğu varsayılmaktadır. Bu şoklar aşağıdaki varyans-kovaryans matrisi ile tanımlanmaktadır.

$$
V=\operatorname{Var}\left(\left[\begin{array}{c}
\varepsilon_{t} \\
\nu_{t} \\
\zeta_{t} \\
\eta_{t}
\end{array}\right]\right)=\left[\begin{array}{cccc}
I_{n} & 0 & 0 & 0 \\
0 & Q & 0 & 0 \\
0 & 0 & S & 0 \\
0 & 0 & 0 & W
\end{array}\right],
$$

Burada $I_{n}$, n boyutlu birim matrisi, $Q, S$ ve $W$ ise pozitif tanımlı matrisleri göstermektedir.

Modelde $V$ yapısına yukarıdaki kısıtların konulması zorunlu değildir. İstenirse tanımlama tüm sıfır elemanlarının yerine sıfır olmayan elemanlar gelecek şekilde de yeniden tanımlanabilmektedir. Ancak $V$ nin bu şekilde tanımlanmasının en önemli nedenlerinden birisi zaman etkisinin de dikkate alınmasıyla ortaya çıkacak çok sayıda parametre hesaplamasının yapılmasını engellemektir (Nakajima, 2011).

\section{Veri}

Çalışmada seçilmiş Avrupa Birliği ülkeleri ve Türkiye'ye ait 1992Q1-2016Q1 dönemini kapsayan çeyreklik veriler kullanılmıştır. AB ülkelerini temsilen Almanya, Fransa, İtalya, İspanya ve İngiltere kullanılmıştır. Mal ve hizmet hareketleri açısından ticari açıklığı gösteren dışa açıklık oranları, ihracat ve ithalat toplamının gayrisafi milli hasılaya oranı şeklinde elde edilmiştir. İşsizlik oranları 15-64 yaş arası genel işsizlik oranlarını kapsamaktadır. Çalışmada ülkeler arasındaki farklılıkları ve bu farklılıkların yol açtığı arz 
şoklarını tanımlamak amacıyla her bir ülkeye ait çıktı açıkları hesaplanmıştır. Bu çıktı açıkları Hodrick-Prescott yöntemiyle her bir ülkenin gayri safi yurtiçi hasılasından elde edilmektedir. AB ve Türkiye'ye ait veriler OECD ve Dünya Bankası veri tabanlarından elde edilmiştir. Modelde kullanılan değişkenken önce mevsimsel etkilerden arındırılmış daha sonra ise logaritmik fark serileri olarak analize dâhil edilmiştir. Katsayıların tahmininde Oxmetrics-7.1 ve WinRats 8 paket programlarından yararlanılmıştır.

Analitik bulguların elde edilmesinde Zamana Göre Değişen Parametreli yaklaşımdan faydalanılmıştır. Söz konusu yaklaşımın tercih edilme nedeni, politika değişimlerinin ve ekonomideki yapısal değişimlerin ele alınan zaman döneminin farklı noktalarında meydana gelmesidir. Bundan dolayı ekonomi politikalarının potansiyel etkilerinin zamana göre değişiminin dikkate alınması gerekmektedir. Dolayısıyla ortak etkiler yerine her bir zaman dönemine ait katsayıların elde edilmesi ekonomideki söz konusu farklı dönemlerde gerçekleşen değişimlerin doğrudan etkisini göstermesi bakımından oldukça etkilidir. TVPVAR tekniğinin standart VAR tekniğinden önemli bir farkı; stokastik oynaklık yaklaşımı ile katsayıların ve varyans-kovaryans matrisinin zamana göre değişime olanak vermesidir. Böylece bu yöntemle yapısal şokların her bir döneme ait ayrı ayrı katsayı tahmini yapılmakta katsayıların zamana göre değişimini dikkate alınmaktadır. $\mathrm{Bu}$ durum incelenen dönem aralığında ekonomide meydana gelen önemli değişmelerin (genişleme, daralma, politika değişiklikleri) katsayılar üzerindeki meydana getirdiği değişikliklerin tahmin edilmesine imkân sağlamaktadır. Böylece karar alma birimlerinin almış olduğu kararların sonuçlarının değerlendirilmesi mümkün olmaktadır.

\section{Bulgular}

Çalışmada Nakajima (2011) tarafından geliştirilen TVP-VAR yaklaşımına dayanılmıştır. TVP-VAR yaklaşımıyla elde edilen parametrelerin teorik açıdan önemi Canova (1993), Sims (1993), Stock ve Watson (1996), Cogley ve Sargent (2005), Primiceri (2005), Benati ve Mumtaz (2005), Canova ve Gambetti (2009), Canova ve Ciccarelli (2009), Koop, Leon-Gonzalez ve Strachan (2009) çalışmalarından görülmektedir. TVP-VAR yaklaşımına dayalı tahminlemede zaman değişkeninin modele dâhil edilmesiyle varyanskovaryans matrisinin aşırı parametreleşme sorunu ortaya çıkabilmektedir (Primiceri, 2005). Genel olarak tahmin edilen katsayılardaki geçici ve kalıcı kaymalar dolayısıyla doğrusal olmayan yapıya sahip seriler rassal yürüyüş süreci izlemektedirler. Bu süreç gözlenemeyen bileşenler ve şoklar arasındaki ayrımın daha etkin bir şekilde ayırt edilebilmesi için ilgili parametrelerin sisteme en son giren bilginin dağılımına (posterior distribution/sonsal dağılım) göre tahmin yapılmasını gerekli kılmaktadır. Bu nedenle de tahminciler Maksimum Olabilirlik yöntemi yerine Bayesgil yöntemler kullanılarak tahmin edilmektedir (Primiceri, 2005: 7). Bu yöntem tahminlemede hem aşırı parametre tahmini sorununa, hem de zamandaki değişmeye bağlı olarak ortaya çıkan doğrusal olmayan yapıya karşı etkin tahmincilerin elde edilmesini sağlamaktadır (Canova vd., 2015: 327). Bayesgil yaklaşımlar simülasyona dayalı Gibbs örnekleme yöntemi ile tahminleme yapabilmektedir. Gibbs örnekleme yöntemi var olan veriden oluşturulan en iyi örneğe göre bir tahmin yapılmasına imkân verir (Korobilis, 2013: 210-211). Bu çalışmada Gibbs örneklemi 2,000'i yakınsamaya ayrılan 10,000 tekrarlamalı simülasyonlarla oluşturulmuştur. Öte yandan çalışmada ele 
alınan döneme ait ilk 25 gözlem (1992Q2-1998Q2 dönemi) verinin dağılımını belirleyen öncül (prior) bilgilerdir (Primiceri, 2005).

Çalışmada kullanılan verilerin birim kök özelliğine sahip olup olmadığının analizine yönelik olarak ADF birim kök testi kullanılmıştır. Dışa açıklık ve işsizlik değişkenlerini temsil eden zaman serileri birim kök özelliğine sahipken, çıktığı açığını temsil eden zaman serisi söz konusu özelliğe sahip değildir. Bundan dolayı dışa açıklık ve işsizlik değişkenlerinin farkı alınarak analizlerin yapılmasına devam edilmiştir. ADF birim kök test sonuçları ekte yer almaktadır.

Dişa açık ekonomiler küresel düzeyde ya da bölgesel düzeyde ekonomik şoklarla karşılaşmaktadır. Bu açıdan bu çalışmada 2008Q3, Küresel Finansal Kriz dönemini; 2010Q4, Avrupa Borç Krizinin başlangıç dönemini ve 2010Q2, Türkiye ekonomisi için Yeni Para Politikası Stratejisine Geçiş döneminin olası etkilerini göstermesi açısından analize dâhil edilmiştir. Ayrıca her döneme ait zamana bağlı ayrı ayrı katsayı tahminleri elde edildiği için söz konusu bu dönemlerin dışındaki birçok kriz, yapısal değişim vb. gibi değişimler de incelenmiş olmaktadır. Örneğin AB'nin hala içinde bulunduğu Likidite Krizi buna örnek verilebilir. Dolayısıyla bu döneme ait katsayılar ve etki tepki fonksiyonları bu etkinin sonuçlarını da göstermiş olmaktadır. Buna göre bu çalışmada şokların ele alınan dönem boyunca asimetrik olup olmadığı test edilmiş olmaktadır. Ayrıca söz konusu asimetrik etkilerin zaman boyutunda farklılaşması da ortaya konmuştur. Böylece hangi zaman döneminde asimetrinin olduğu görülmüştür. $\mathrm{Bu}$ iktisat politikalarının sonuçlarının değerlendirilmesi açısından bilgi sunmaktadır. Bu açıdan değerlendirildiğinde kullanılan yaklaşım ve tahmin tekniği çalışmanın özgünlüğünü ve katkısını ortaya koymaktadır.

Bu çalışmada temel TVP-VAR modeli (outgap, op, unp) şeklinde tanımlanmıştır. Tahminleme aşamasında Nakajima (2009)'un yöntemine göre maksimum gecikme uzunluğu 5 olarak, en yüksek marjinal olasılık değerini veren gecikme uzunluğu 2 olarak belirlenmiştir. Tahminleme sürecinde parametre tahmininde kullanılan yaklaşımın çözümlenmesinde kullanılan algoritma olan MCMC ile simülasyona başlamadan önce başlangıç parametre değerleri aşağıdaki gibi verilmektedir (Nakajima, 2011).

$$
\mu_{\beta 0}=\mu_{a 0}=\mu_{h 0}=0 \text { ve } \sum_{\beta 0}=\sum_{a 0}=\sum_{h 0}=10 \times I
$$

Bu değerlere bağlı olarak varsayılan başlangıç tanımları aşağıdaki eşitlikteki gibidir:

$$
\left(\sum \beta\right)^{-2} \backsim \operatorname{Gamma}(20,0.02),\left(\sum a\right)^{-2} \backsim \operatorname{Gamma}(4,0.02),\left(\sum h\right)^{-2} \backsim \operatorname{Gamma}(4,0.02)
$$

$\mathrm{Bu}$ eşitlikler yoluyla verideki son bilgilerin veya verinin dağılımına bağlı tahminler $\mathrm{M}=10,000$ tekrarlamayla parametreler hesaplanmaktadır. Bu parametrelere ait tahmin sonuçları aşağıdaki tablolarda görülmektedir: 


\section{Fransa}

Tablo: 1

TVP-VAR Parametre Tahmin Sonucları

\begin{tabular}{|l|c|c|c|c|c|}
\hline \multicolumn{1}{|c|}{ Parametre } & Ortalama & S.sapma & \%95 güven aralıkları & CD & Etkinsizlik \\
\hline$\left(\sum_{\beta}\right)_{1}$ & 0.0222 & 0.0026 & {$[0.0182,0.0283]$} & 0.155 & 5.39 \\
\hline$\left(\sum_{\beta}\right)_{2}$ & 0.0226 & 0.0182 & {$[0.0182,0.0283]$} & 0.467 & 6.80 \\
\hline$\left(\sum_{a}\right)_{1}$ & 0.0811 & 0.0417 & {$[0.0417,0.1612]$} & 0.371 & 34.47 \\
\hline$\left(\sum_{a}\right)_{2}$ & 0.1075 & 0.0438 & {$[0.0438,0.2997]$} & 0.760 & 98.16 \\
\hline$\left(\sum_{h}\right)_{1}$ & 0.6774 & 0.4992 & {$[0.4992,0.9089]$} & 0.701 & 70.76 \\
\hline$\left(\sum_{h}\right)_{2}$ & 0.6334 & 0.4754 & {$[0.4754,0.8522]$} & 0.893 & 46.56 \\
\hline
\end{tabular}

$s_{b 1}=\left(\sum_{\beta}\right)_{1}, s_{b 2}=\left(\sum_{\beta}\right)_{2}, s_{a 1}=\left(\sum_{a}\right)_{1}, s_{a 2}=\left(\sum_{a}\right)_{2}, s_{h 1}=\left(\sum_{h}\right)_{1}, s_{h 2}=\left(\sum_{h}\right)_{2}$

Şekil: 1

\section{Örneklem Otokorelasyon, Örneklem Patikası ve Sonsal Yoğunluk Fonksiyonu}

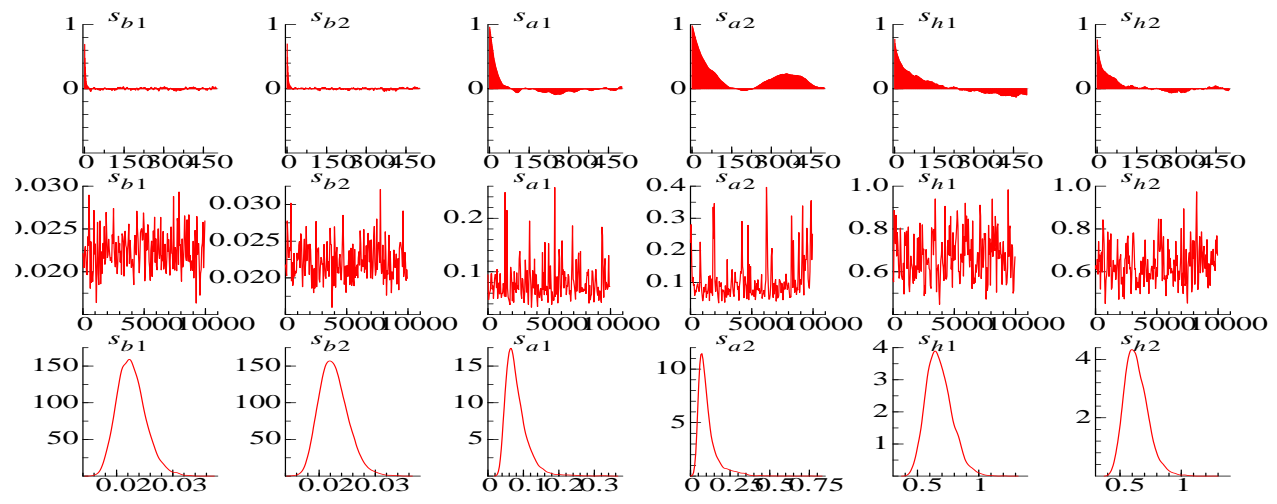

Şekil: 2

Yapısal Şokların Stokastik Oynaklığı

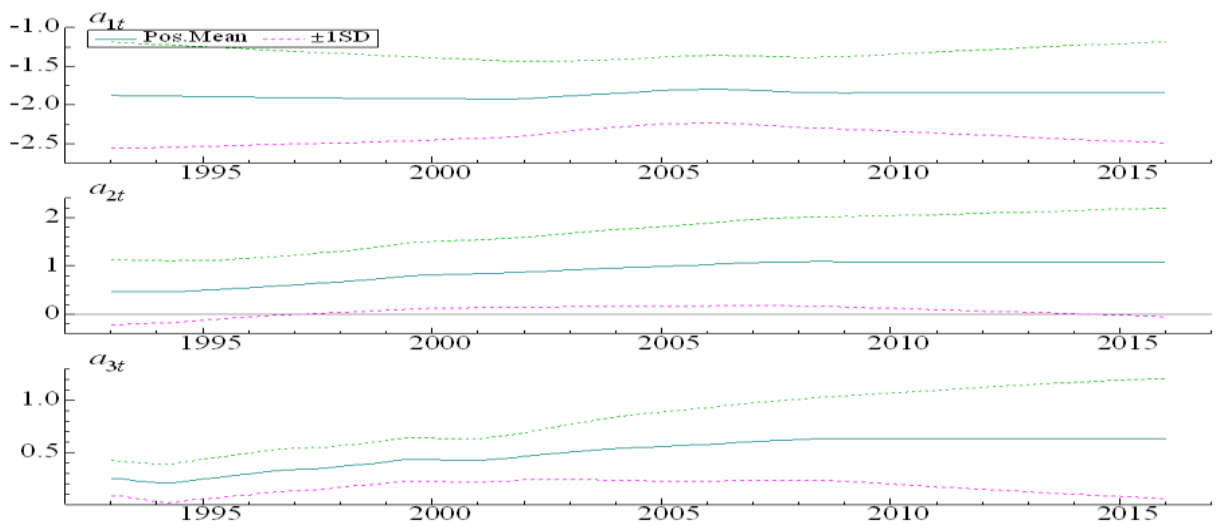




\section{Sekil: 3}

\section{Eşanlı İlişkilerin Sonsal Tahmini}
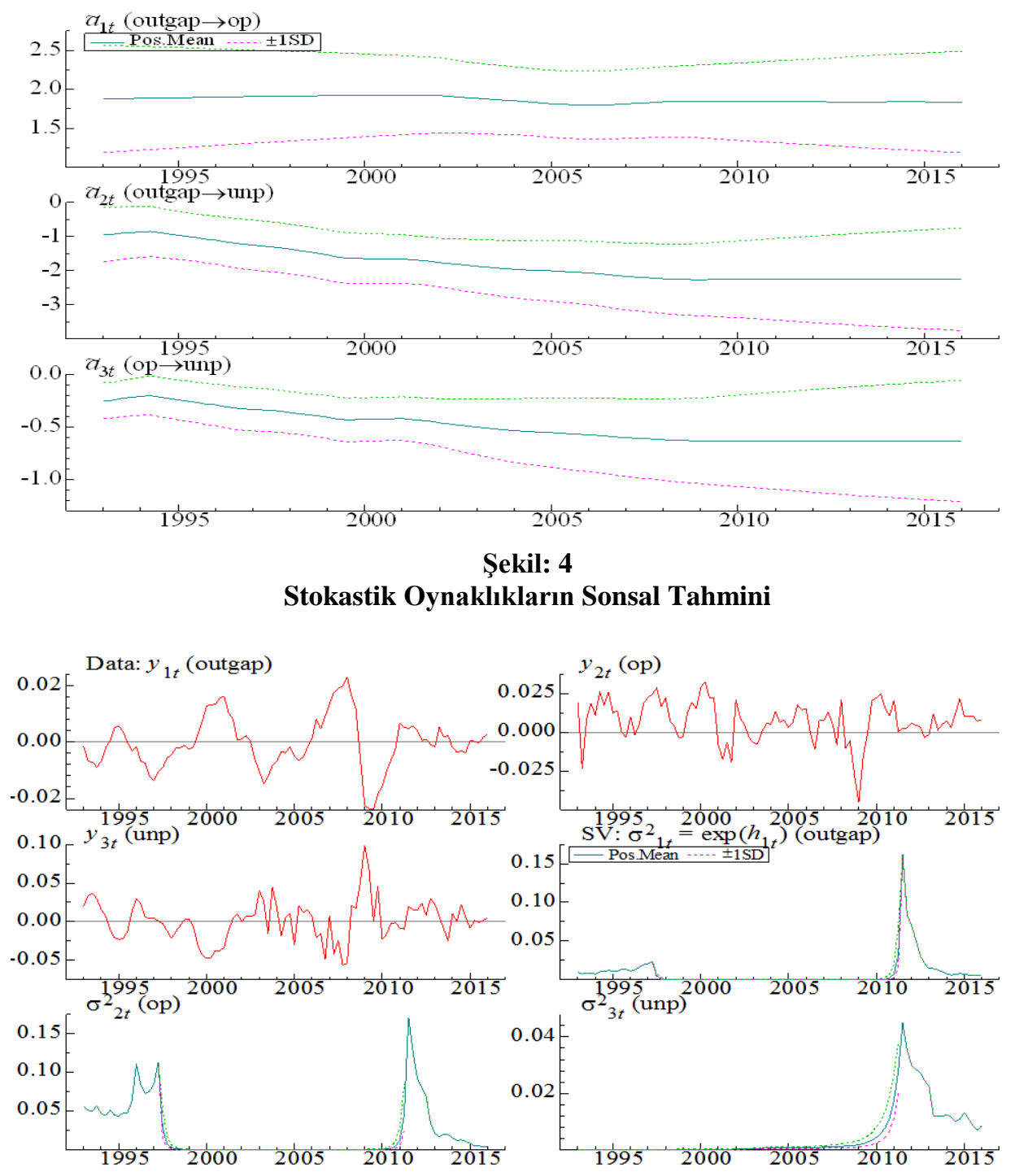


\section{Şekil: 5}

\section{TVP-VAR Modeli Etki-Tepki Fonksiyonları}

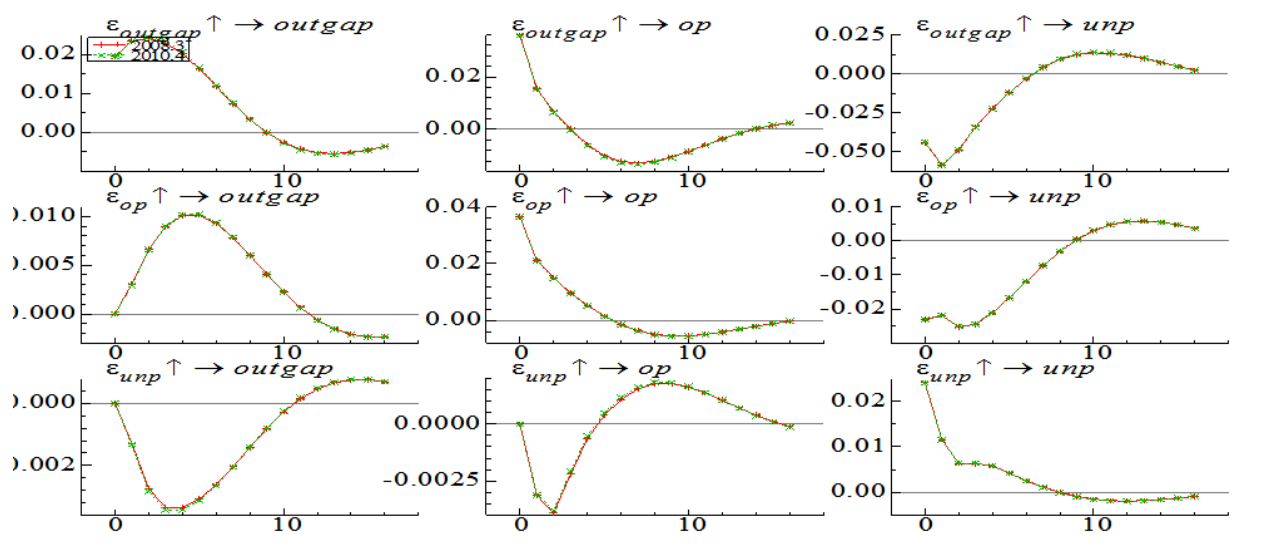

Almanya

Tablo: 2

TVP-VAR Parametre Tahmin Sonuçları

\begin{tabular}{|l|c|c|c|c|c|}
\hline \multicolumn{1}{|c|}{ Parametre } & Ortalama & S.sapma & \%95 güven aralıkları & CD & Etkinsizlik \\
\hline$\left(\sum_{\beta}\right)_{1}$ & 0.0226 & 0.0026 & {$[0.0182,0.0282]$} & 0.340 & 6.35 \\
\hline$\left(\sum_{\beta}\right)_{2}$ & 0.0228 & 0.0026 & {$[0.0184,0.0287]$} & 0.134 & 5.05 \\
\hline$\left(\sum_{a}\right)_{1}$ & 0.0881 & 0.0401 & {$[0.0440,0.2004]$} & 0.483 & 38.66 \\
\hline$\left(\sum_{a}\right)_{2}$ & 0.1039 & 0.0425 & {$[0.0457,0.2084]$} & 0.714 & 35.95 \\
\hline$\left(\sum_{h}\right)_{1}$ & 0.4833 & 0.0662 & {$[0.3724,0.6311]$} & 0.788 & 33.41 \\
\hline$\left(\sum_{h}\right)_{2}$ & 0.5667 & 0.0930 & {$[0.4063,0.7697]$} & 0.873 & 35.47 \\
\hline
\end{tabular}

$s_{b 1}=\left(\sum_{\beta}\right)_{1}, s_{b 2}=\left(\sum_{\beta}\right)_{2}, s_{a 1}=\left(\sum_{a}\right)_{1}, s_{a 2}=\left(\sum_{a}\right)_{2}, s_{h 1}=\left(\sum_{h}\right)_{1}, s_{h 2}=\left(\sum_{h}\right)_{2}$ 
Şekil: 6

\section{Örneklem Otokorelasyon, Örneklem Patikası ve Sonsal Yoğunluk Fonksiyonu}
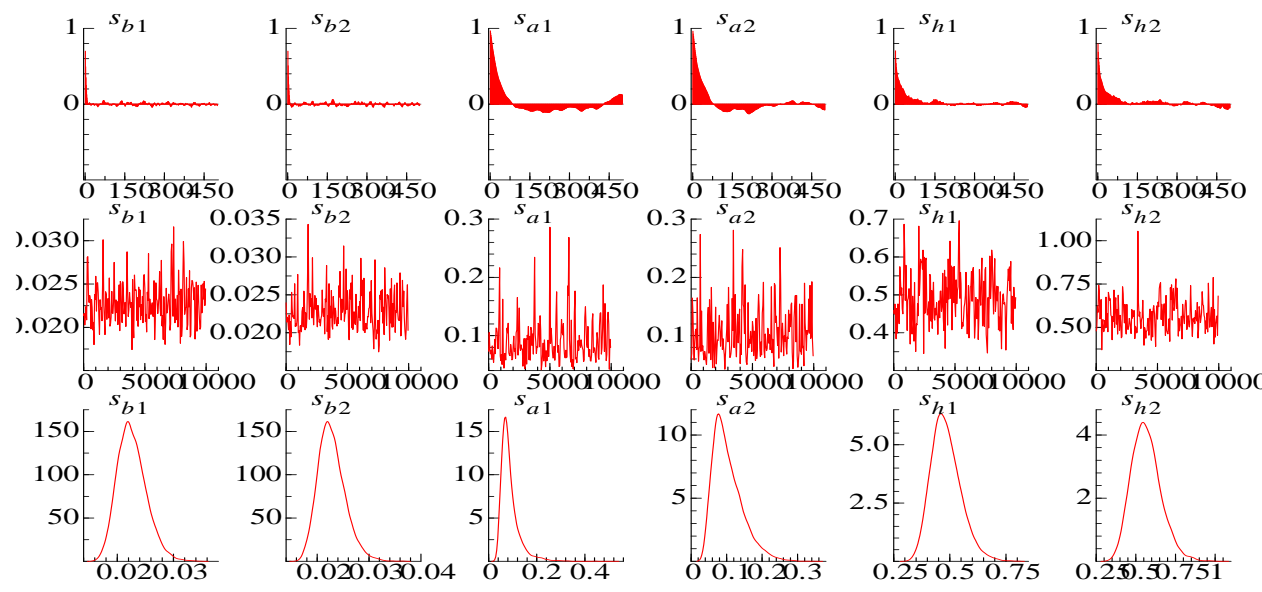

Şekil: 7

Yapısal Şokların Stokastik Oynaklığı

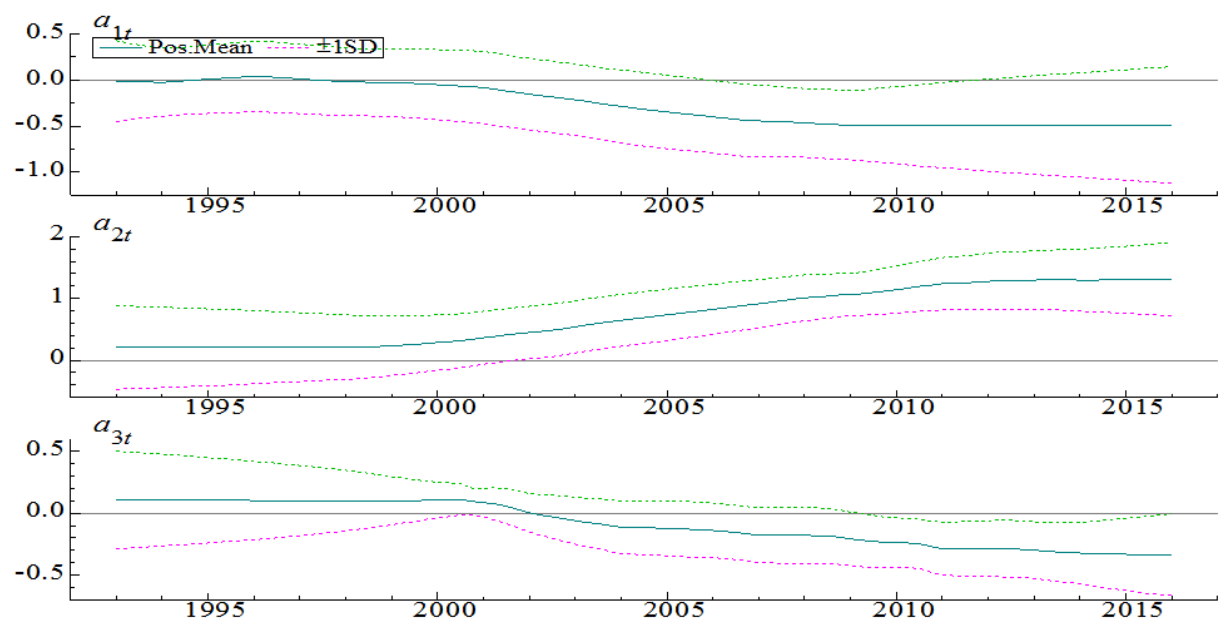


Şekil: 8

\section{Eşanlı İlişkilerin Sonsal Tahmini}

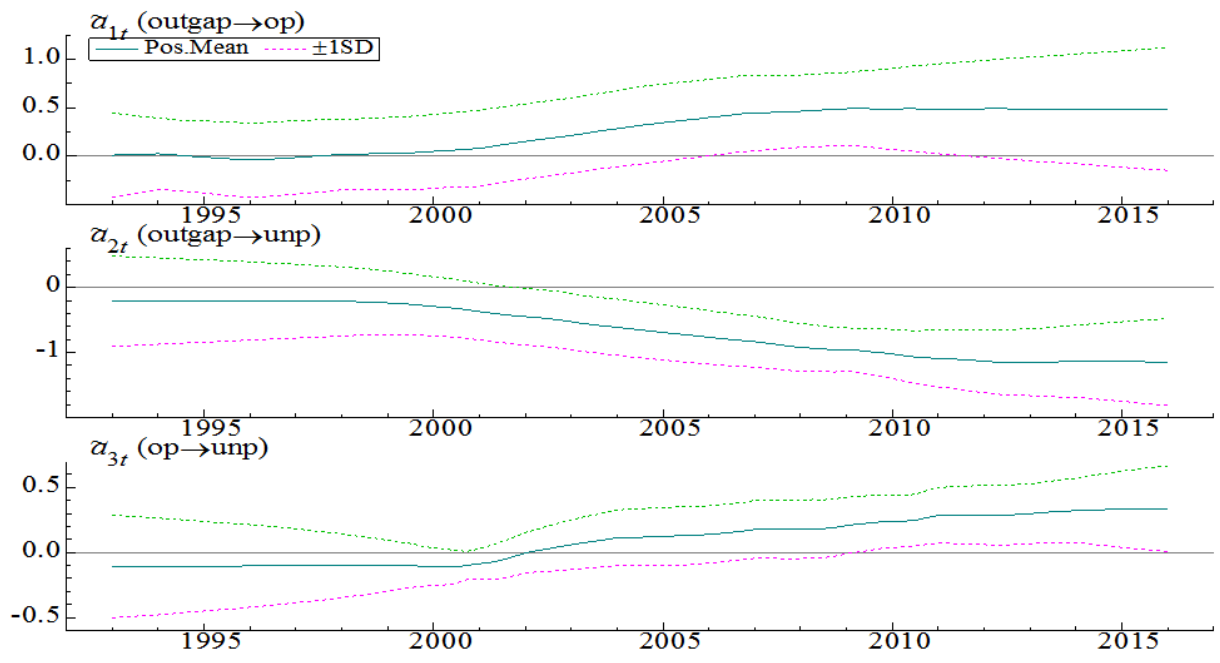

Şekil: 9

Stokastik Oynaklıkların Sonsal Tahmini

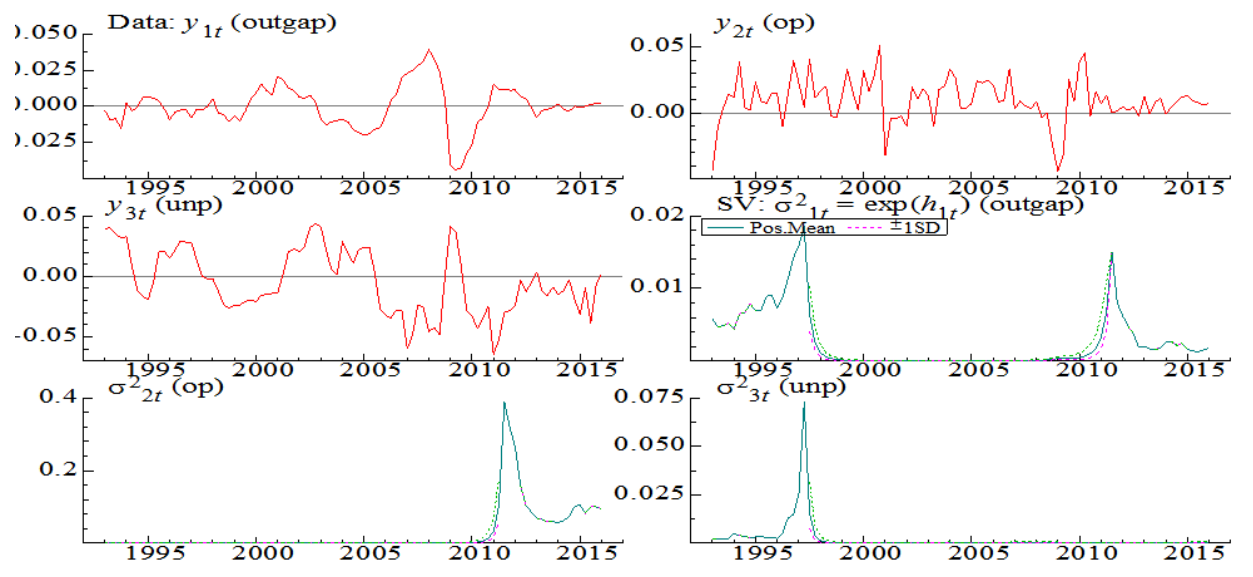


Şekil: 10

TVP-VAR Modeli Etki-Tepki Fonksiyonları

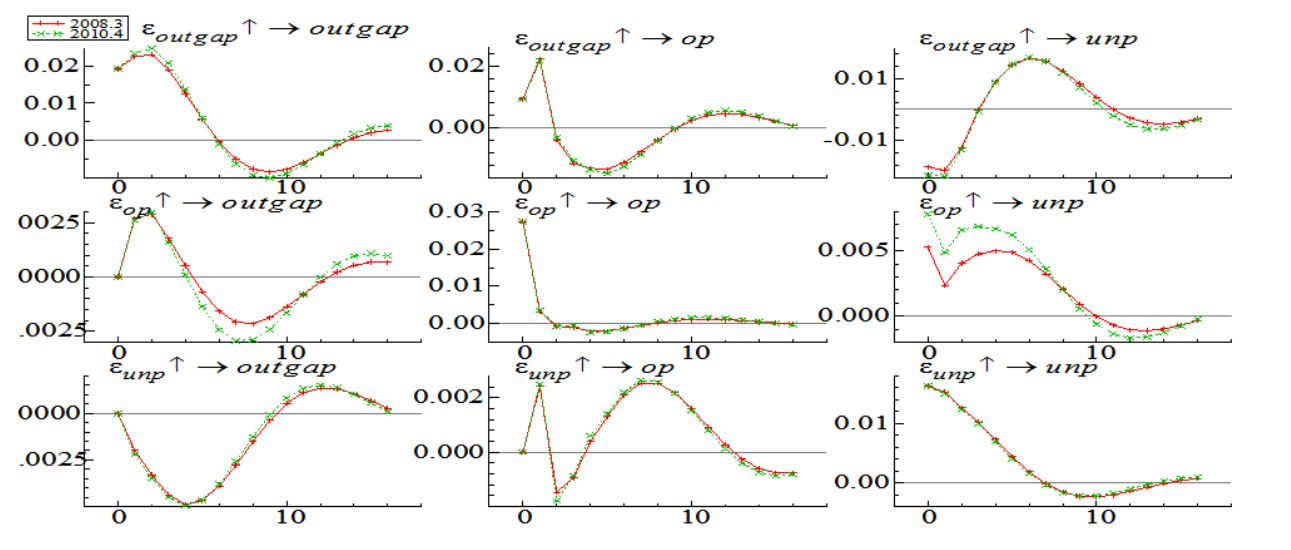

İtalya

Tablo: 3

TVP-VAR Parametre Tahmin Sonuçları

\begin{tabular}{|l|c|c|c|c|c|}
\hline \multicolumn{1}{|c|}{ Parametre } & Ortalama & S.sapma & \%95 güven aralıkları & CD & Etkinsizlik \\
\hline$\left(\sum_{\beta}\right)_{1}$ & 0.0227 & 0.0026 & {$[0.0183,0.0283]$} & 0.131 & 6.01 \\
\hline$\left(\sum_{\beta}\right)_{2}$ & 0.0227 & 0.0026 & {$[0.0183,0.0284]$} & 0.066 & 5.54 \\
\hline$\left(\sum_{a}\right)_{1}$ & 0.1066 & 0.0561 & {$[0.0452,0.2512]$} & 0.282 & 47.37 \\
\hline$\left(\sum_{a}\right)_{2}$ & 0.0864 & 0.0386 & {$[0.0410,0.1892]$} & 0.179 & 53.98 \\
\hline$\left(\sum_{h}\right)_{1}$ & 0.6383 & 0.0884 & {$[0.4860,0.8284]$} & 0.184 & 37.29 \\
\hline$\left(\sum_{h}\right)_{2}$ & 0.5190 & 0.0920 & {$[0.3701,0.7270]$} & 0.698 & 28.09 \\
\hline
\end{tabular}

$s_{b 1}=\left(\sum_{\beta}\right)_{1}, s_{b 2}=\left(\sum_{\beta}\right)_{2}, s_{a 1}=\left(\sum_{a}\right)_{1}, s_{a 2}=\left(\sum_{a}\right)_{2}, s_{h 1}=\left(\sum_{h}\right)_{1}, s_{h 2}=\left(\sum_{h}\right)_{2}$ 


\section{Sekil: 11}

\section{Örneklem Otokorelasyon, Örneklem Patikası ve Sonsal Yoğunluk Fonksiyonu}

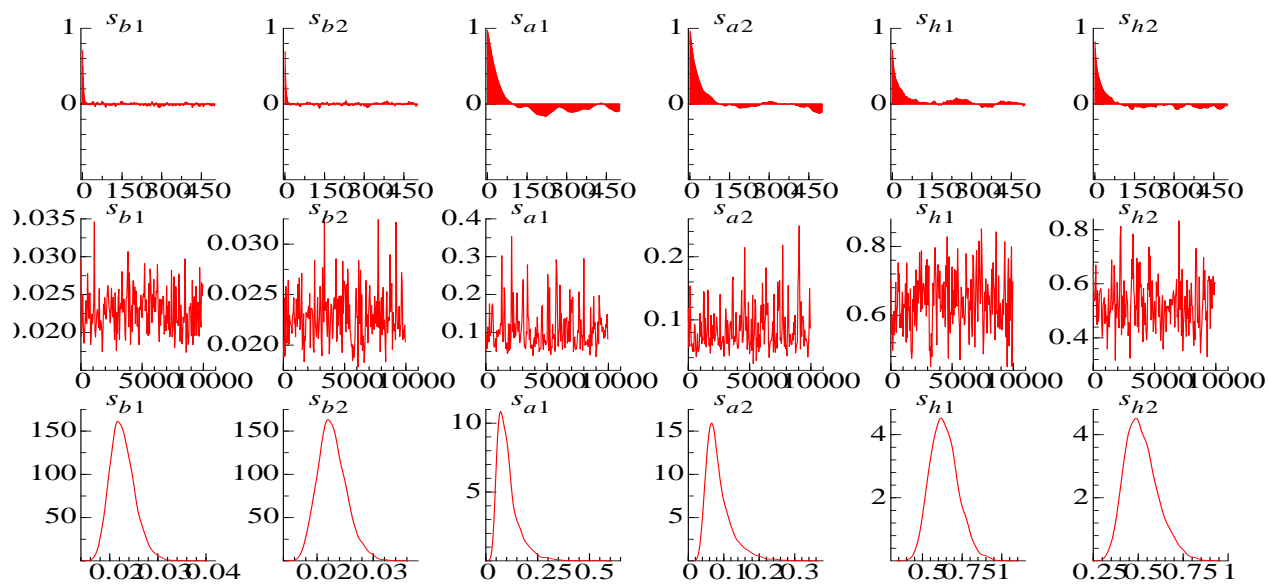

Şekil: 12

Yapısal Şokların Stokastik Oynaklığı
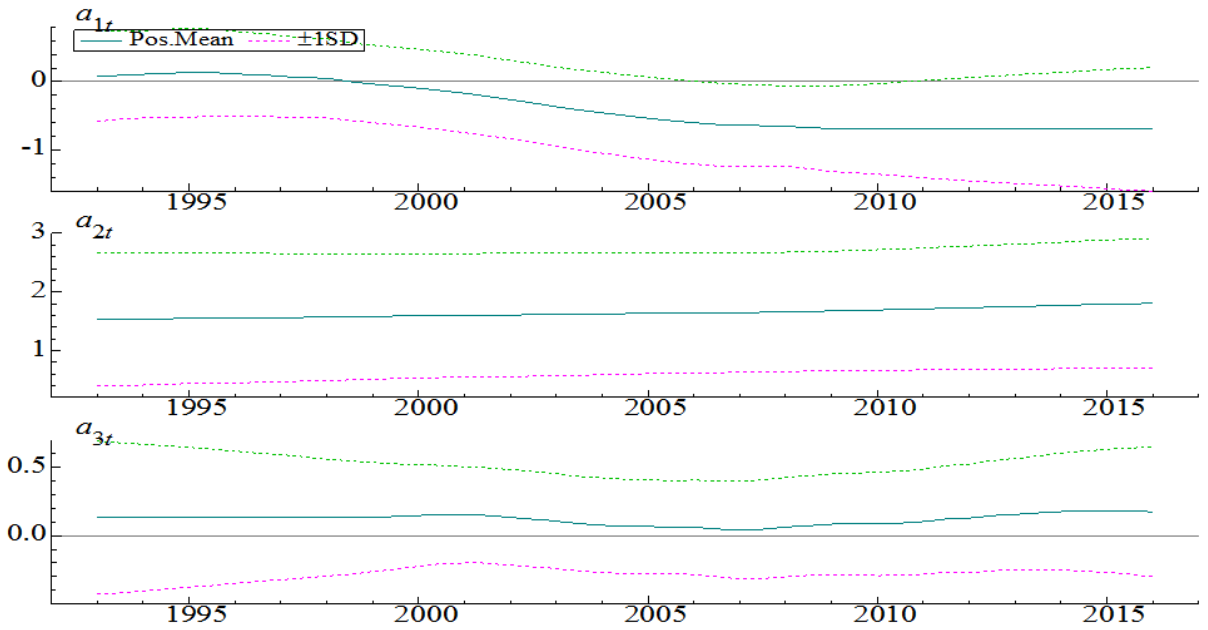


\section{Sekil: 13}

\section{Eşanlı İlişkilerin Sonsal Tahmini}
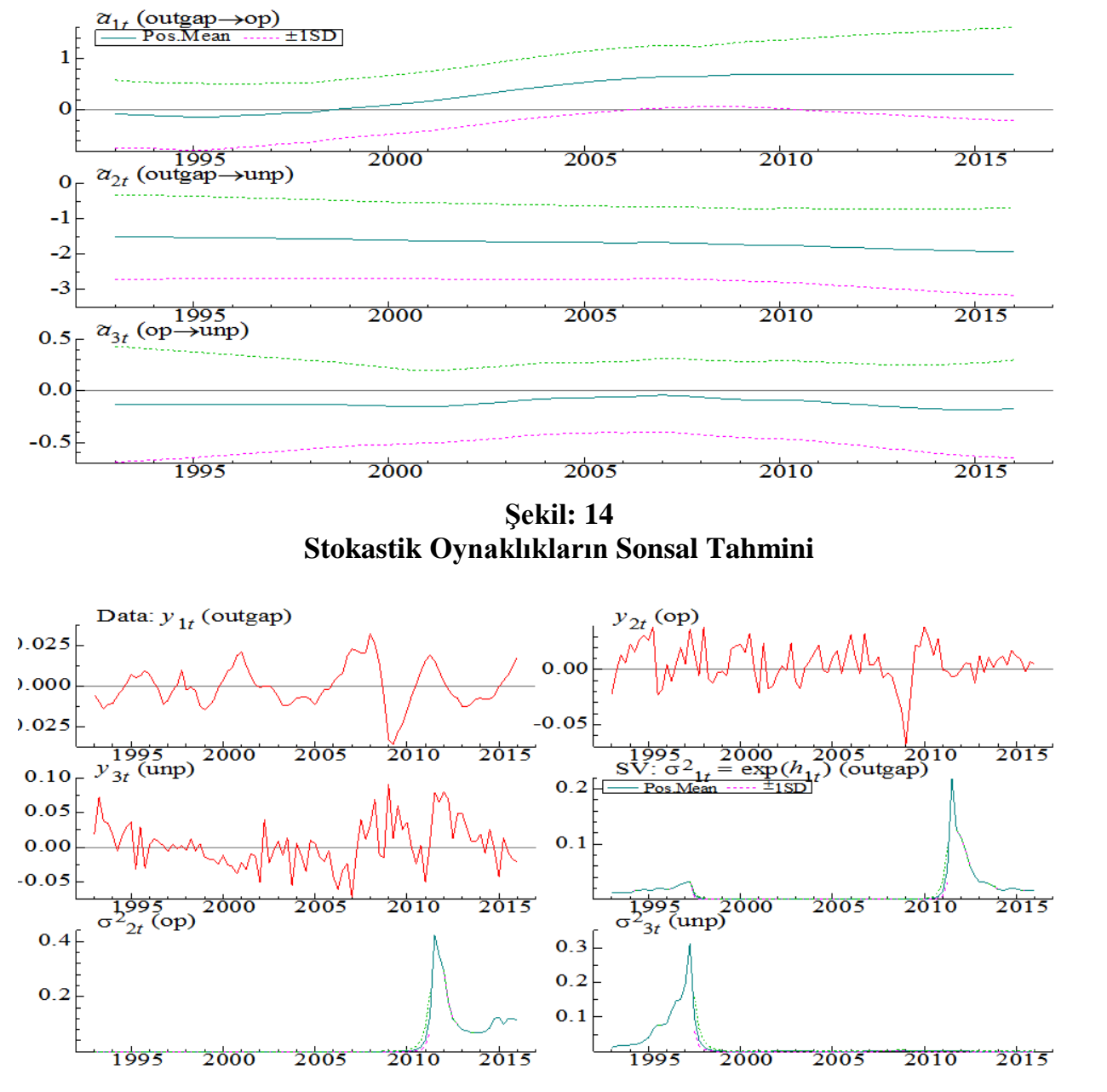
Şekil: 15

TVP-VAR Modeli Etki-Tepki Fonksiyonları

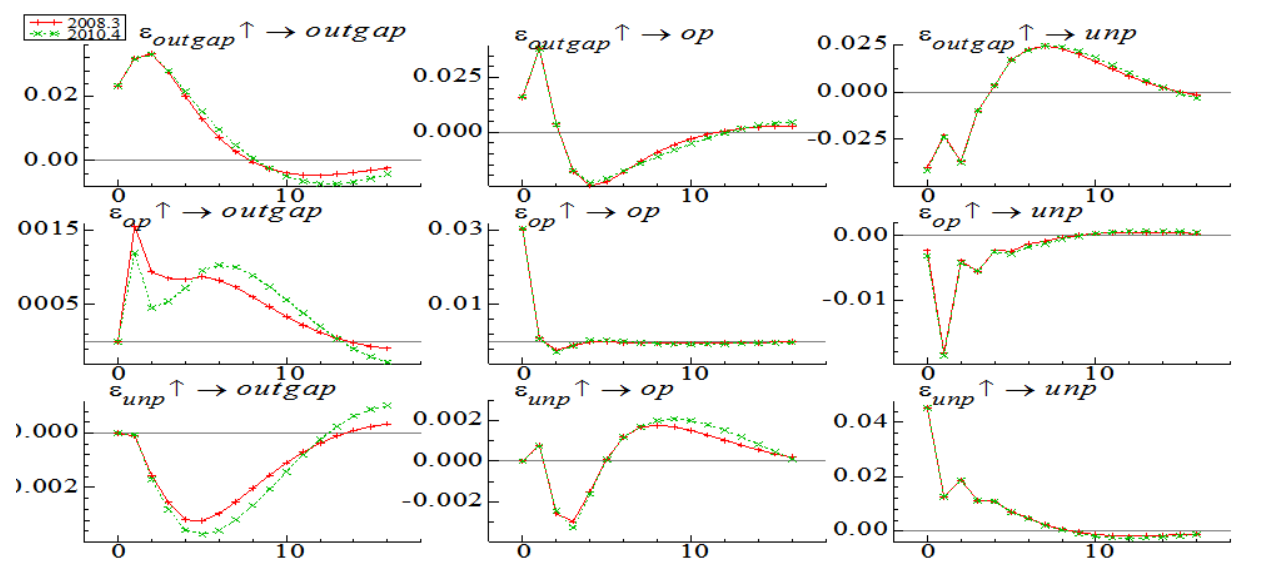

İspanya

Tablo: 4

TVP-VAR Parametre Tahmin Sonuçları

\begin{tabular}{|l|c|c|c|c|c|}
\hline \multicolumn{1}{|c|}{ Parametre } & Ortalama & S.sapma & \%95 güven aralıları & CD & Etkinsizlik Faktörü \\
\hline$\left(\sum_{\beta}\right)_{1}$ & 0.0229 & 0.0026 & {$[0.0184,0.0286]$} & 0.909 & 6.57 \\
\hline$\left(\sum_{\beta}\right)_{2}$ & 0.0225 & 0.0025 & {$[0.0182,0.0281]$} & 0.096 & 6.14 \\
\hline$\left(\sum_{a}\right)_{1}$ & 0.0864 & 0.0378 & {$[0.0427,0.1935]$} & 0.792 & 52.30 \\
\hline$\left(\sum_{a}\right)_{2}$ & 0.0877 & 0.0361 & {$[0.0443,0.1795]$} & 0.643 & 51.74 \\
\hline$\left(\sum_{h}\right)_{1}$ & 0.7296 & 0.1065 & {$[0.5540,0.9654]$} & 0.400 & 54.84 \\
\hline$\left(\sum_{h}\right)_{2}$ & 0.6172 & 0.1032 & {$[0.4460,0.8488]$} & 0.878 & 76.73 \\
\hline
\end{tabular}

$s_{b 1}=\left(\sum_{\beta}\right)_{1}, s_{b 2}=\left(\sum_{\beta}\right)_{2}, s_{a 1}=\left(\sum_{a}\right)_{1}, s_{a 2}=\left(\sum_{a}\right)_{2}, s_{h 1}=\left(\sum_{h}\right)_{1}, s_{h 2}=\left(\sum_{h}\right)_{2}$ 
Şekil: 16

\section{Örneklem Otokorelasyon, Örneklem Patikası ve Sonsal Yoğunluk Fonksiyonu}

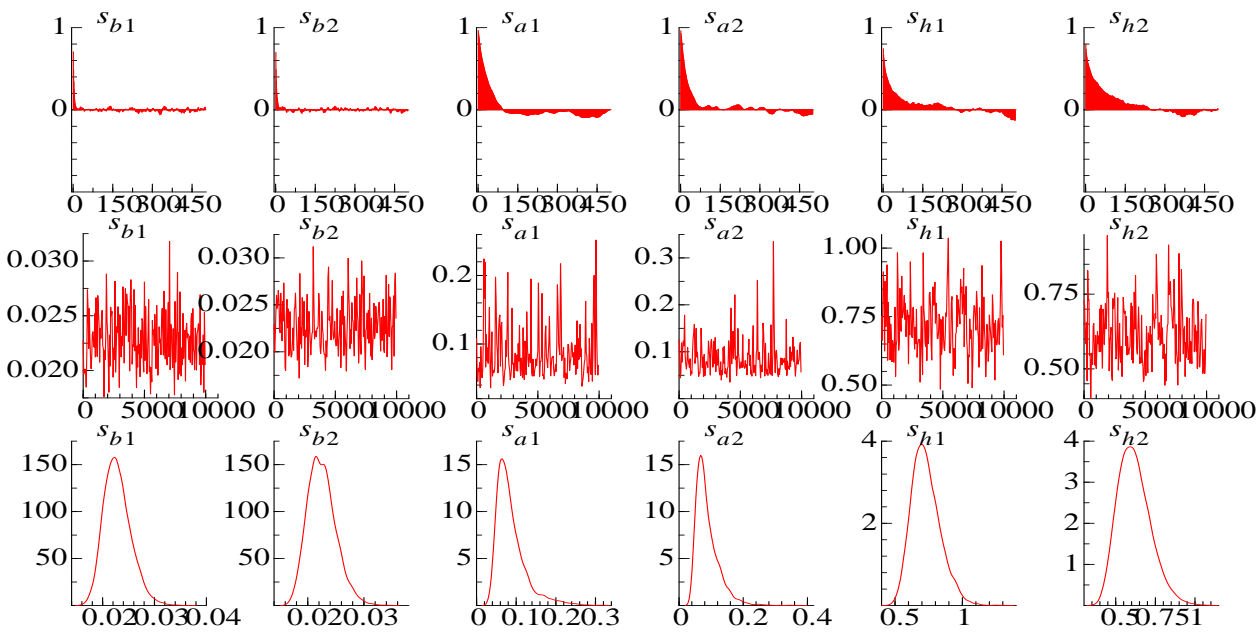

Şekil: 17

Yapısal Şokların Stokastik Oynaklı̆ğ

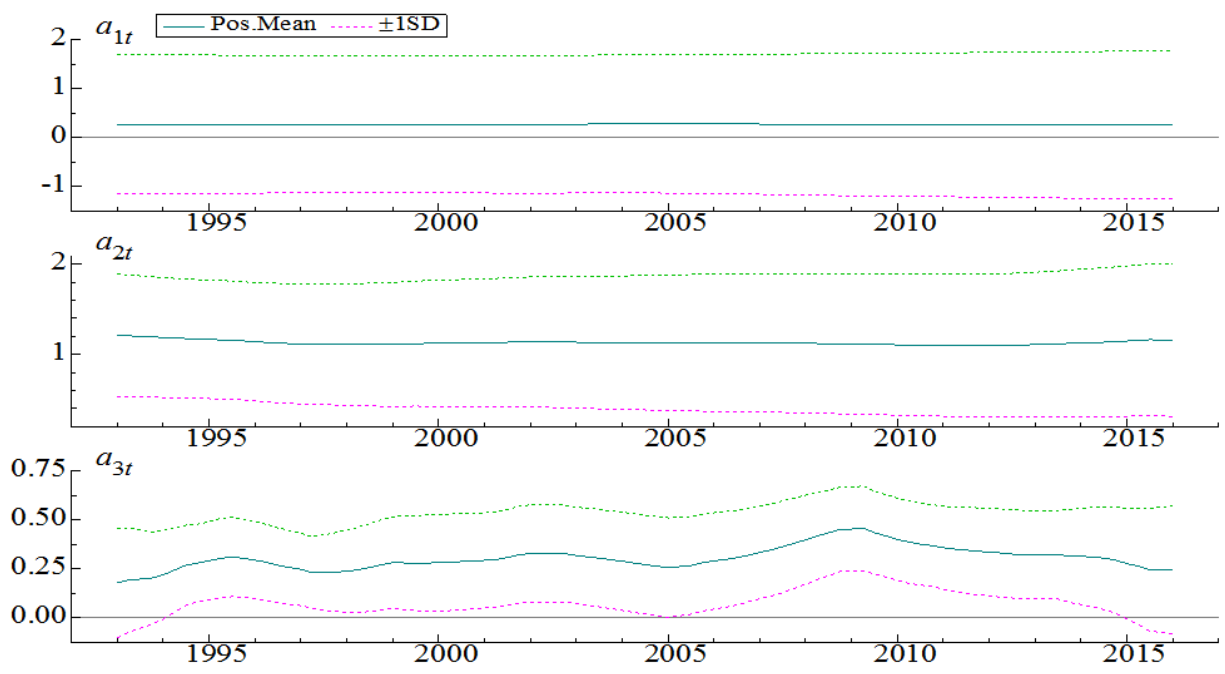


Şekil: 18

\section{Eşanlı İlişkilerin Sonsal Tahmini}

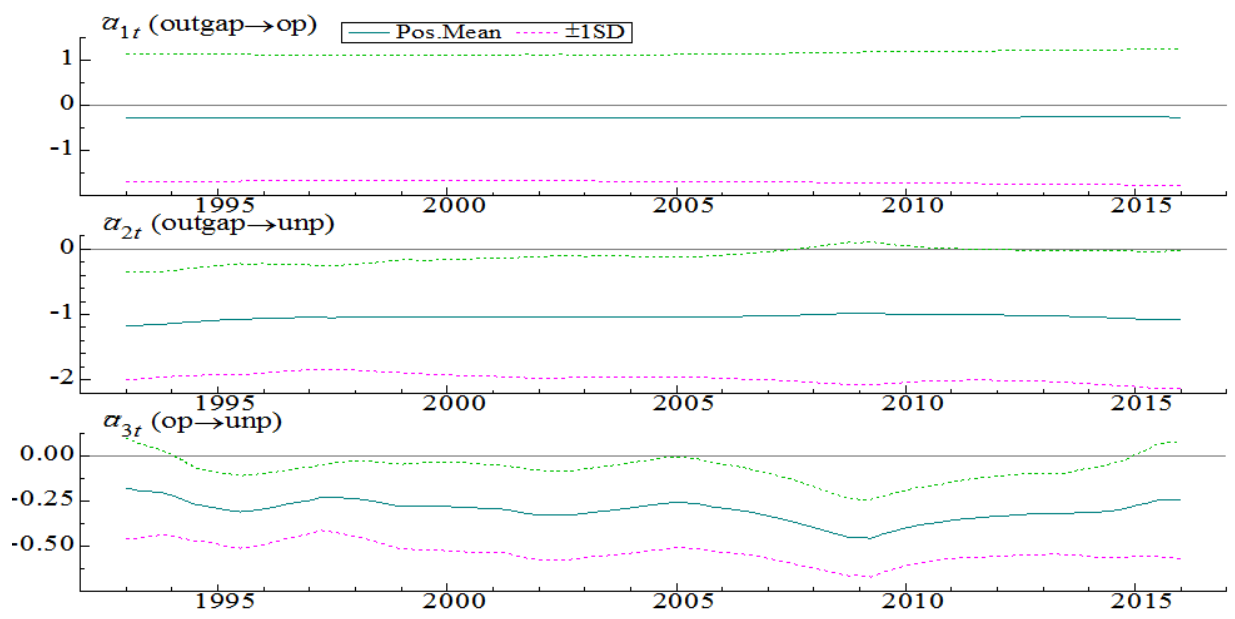

Şekil: 19

Stokastik Oynaklıkların Sonsal Tahmini

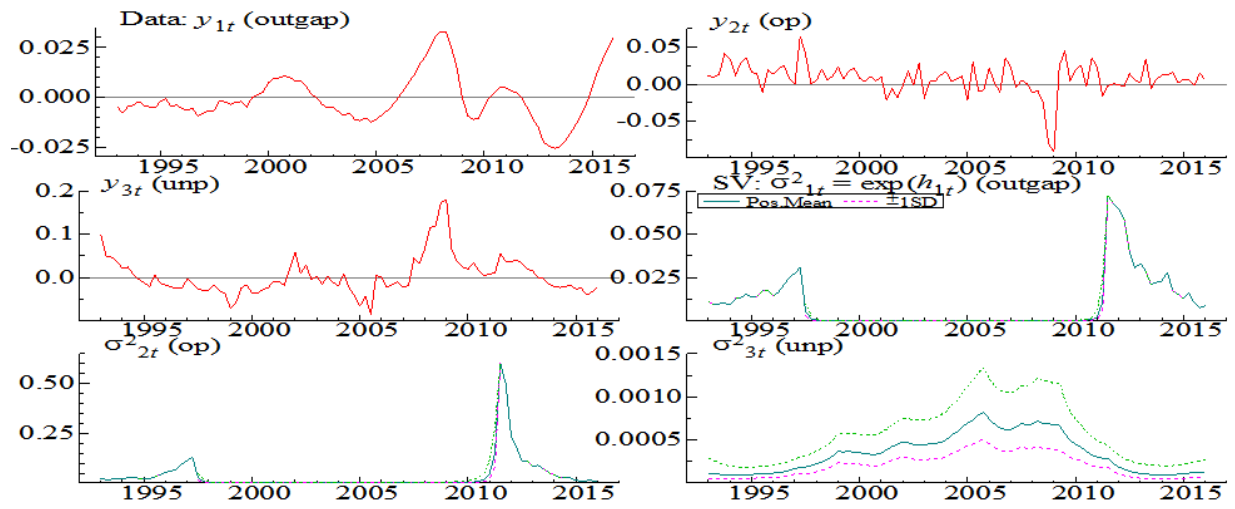


Şekil: 20

TVP-VAR Modeli Etki-Tepki Fonksiyonları

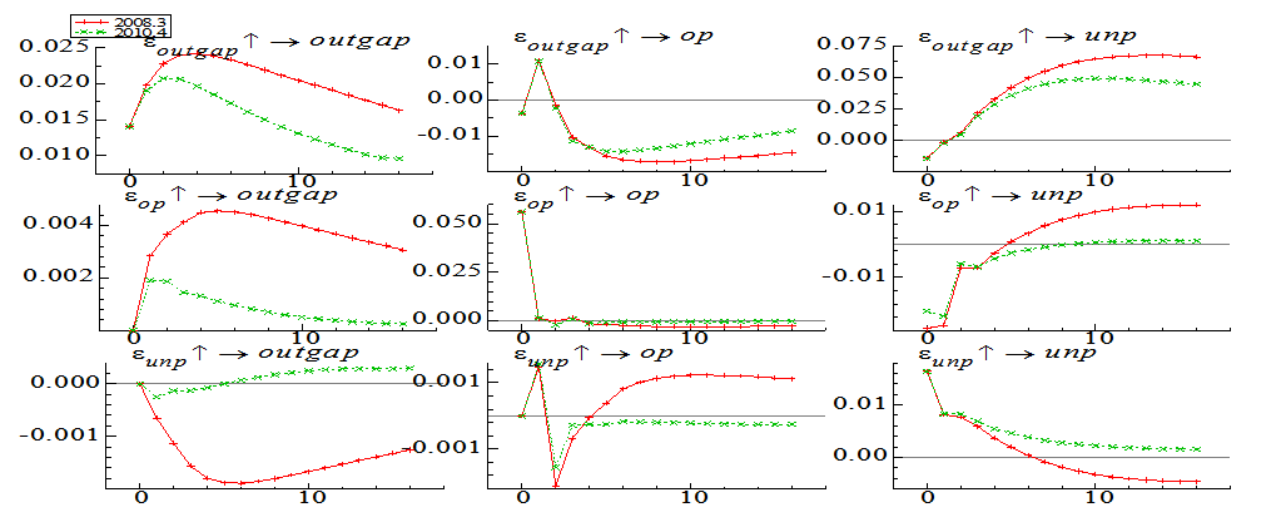

\section{İngiltere}

Tablo: 5

TVP-VAR Parametre Tahmin Sonuçları

\begin{tabular}{|l|l|l|r|l|l|}
\hline Parametre & Ortalama & S.sapma & \%95 güven aralılar1 & CD & Etkinsizlik \\
\hline$\left(\sum_{\beta}\right)_{1}$ & 0.0229 & 0.0027 & {$[0.0185,0.0290]$} & 0.009 & 7.79 \\
\hline$\left(\sum_{\beta}\right)_{2}$ & 0.0225 & 0.0025 & {$[0.0183,0.0278]$} & 0.001 & 5.16 \\
\hline$\left(\sum_{a}\right)_{1}$ & 0.0941 & 0.0480 & {$[0.0430,0.2233]$} & 0.967 & 96.01 \\
\hline$\left(\sum_{a}\right)_{2}$ & 0.0883 & 0.0440 & {$[0.0419,0.2070]$} & 0.215 & 89.69 \\
\hline$\left(\sum_{h}\right)_{1}$ & 0.6999 & 0.1116 & {$[0.5136,0.9521]$} & 0.451 & 75.68 \\
\hline$\left(\sum_{h}\right)_{2}$ & 0.6340 & 0.0964 & {$[0.4654,0.8479]$} & 0.417 & 58.46 \\
\hline
\end{tabular}

$s_{b 1}=\left(\sum_{\beta}\right)_{1}, s_{b 2}=\left(\sum_{\beta}\right)_{2}, s_{a 1}=\left(\sum_{a}\right)_{1}, s_{a 2}=\left(\sum_{a}\right)_{2}, s_{h 1}=\left(\sum_{h}\right)_{1}, s_{h 2}=\left(\sum_{h}\right)_{2}$ 
Şekil: 21

\section{Örneklem Otokorelasyon, Örneklem Patikası ve Sonsal Yoğunluk Fonksiyonu}

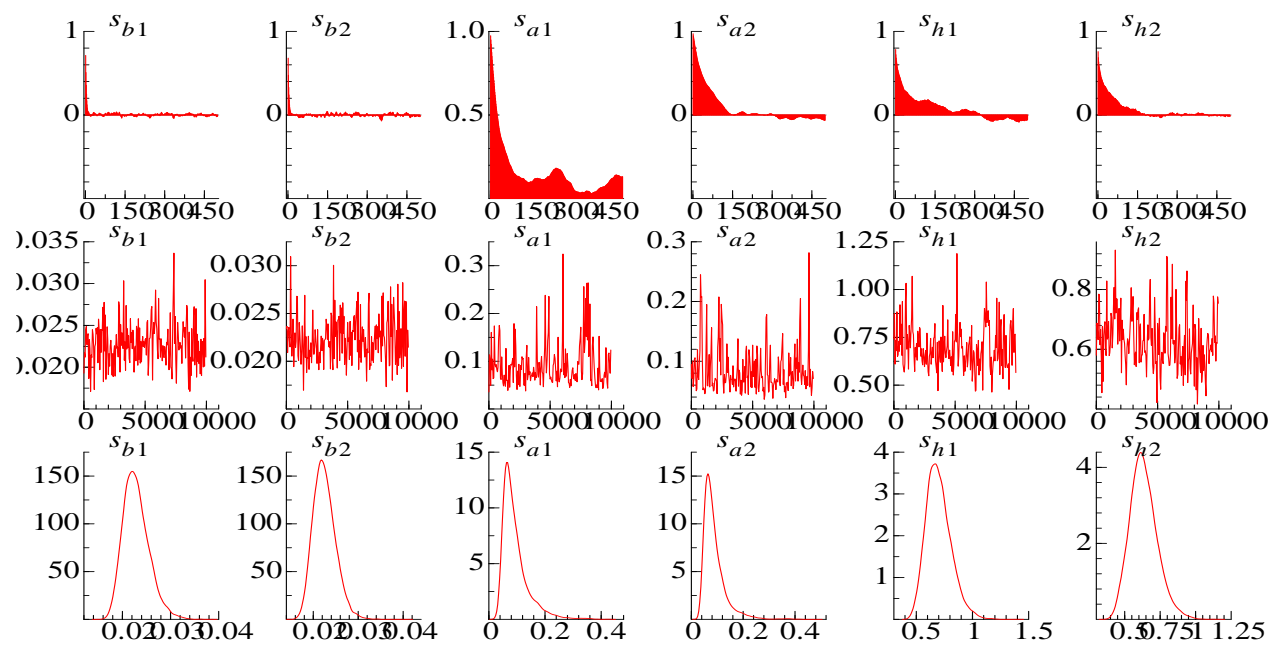

Şekil: 22

TVP-VAR Modeli Etki-Tepki Fonksiyonları

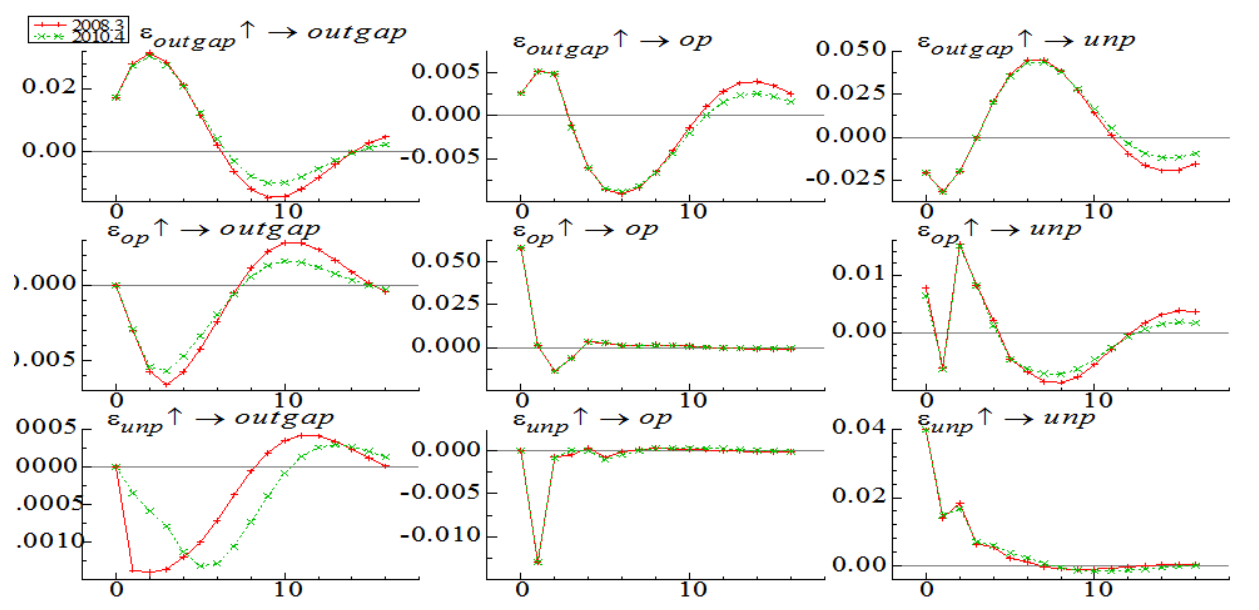




\section{Türkiye}

Tablo: 6

TVP-VAR Parametre Tahmin Sonuçları

\begin{tabular}{|l|l|l|r|r|l|}
\hline Parametre & Ortalama & S.sapma & \%95 güven aralıkları & CD & Etkinsizlik \\
\hline$\left(\sum_{\beta}\right)_{1}$ & 0.0227 & 0.0026 & {$[0.0183,0.0286]$} & 0.890 & 6.48 \\
\hline$\left(\sum_{\beta}\right)_{2}$ & 0.0228 & 0.0026 & {$[0.0184,0.0285]$} & 0.141 & 6.82 \\
\hline$\left(\sum_{a}\right)_{1}$ & 0.0688 & 0.0220 & {$[0.0394,0.1256]$} & 0.780 & 35.03 \\
\hline$\left(\sum_{a}\right)_{2}$ & 0.0675 & 0.0217 & {$[0.0388,0.1247]$} & 0.966 & 35.71 \\
\hline$\left(\sum_{h}\right)_{1}$ & 0.2048 & 0.0754 & {$[0.0929,0.3920]$} & 0.450 & 68.86 \\
\hline$\left(\sum_{h}\right)_{2}$ & 0.3220 & 0.1318 & {$[0.1253,0.6259]$} & 0.638 & 62.15 \\
\hline
\end{tabular}

$s_{b 1}=\left(\sum_{\beta}\right)_{1}, s_{b 2}=\left(\sum_{\beta}\right)_{2}, s_{a 1}=\left(\sum_{a}\right)_{1}, s_{a 2}=\left(\sum_{a}\right)_{2}, s_{h 1}=\left(\sum_{h}\right)_{1}, s_{h 2}=\left(\sum_{h}\right)_{2}$

Şekil: 23

\section{Örneklem Otokorelasyon, Örneklem Patikası ve Sonsal Yoğunluk Fonksiyonu}

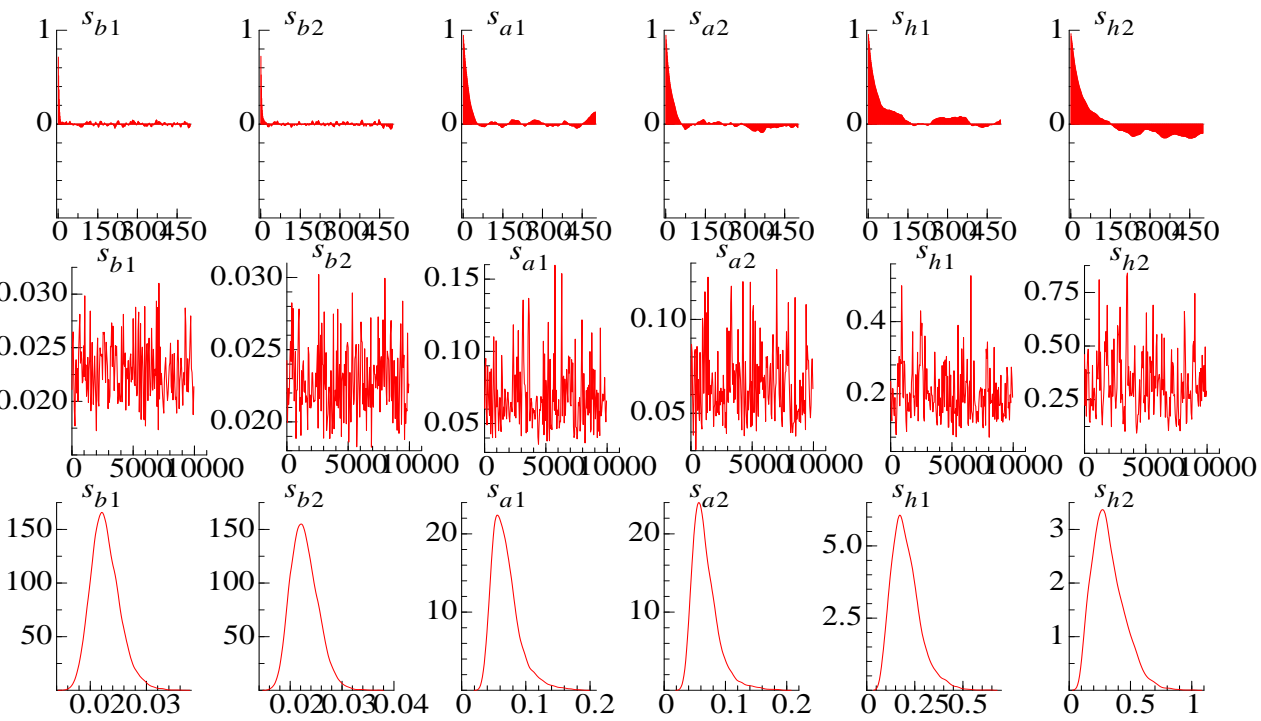




\section{Şekil: 24}

\section{Yapısal Şokların Stokastik Oynaklığı}
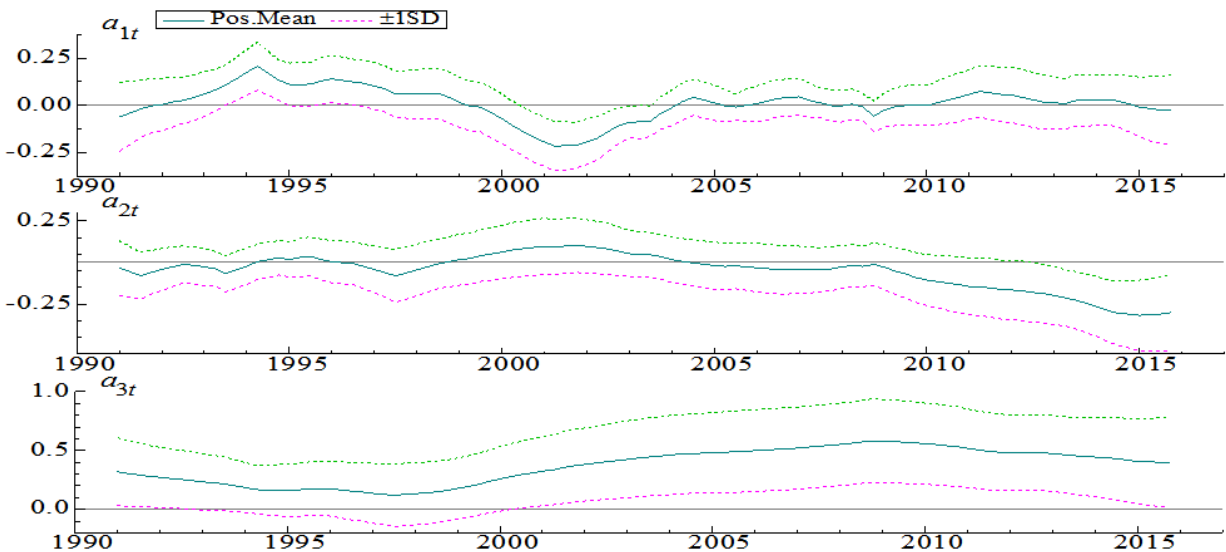

Şekil: 25

Eşanlı İlişskilerin Sonsal Tahmini

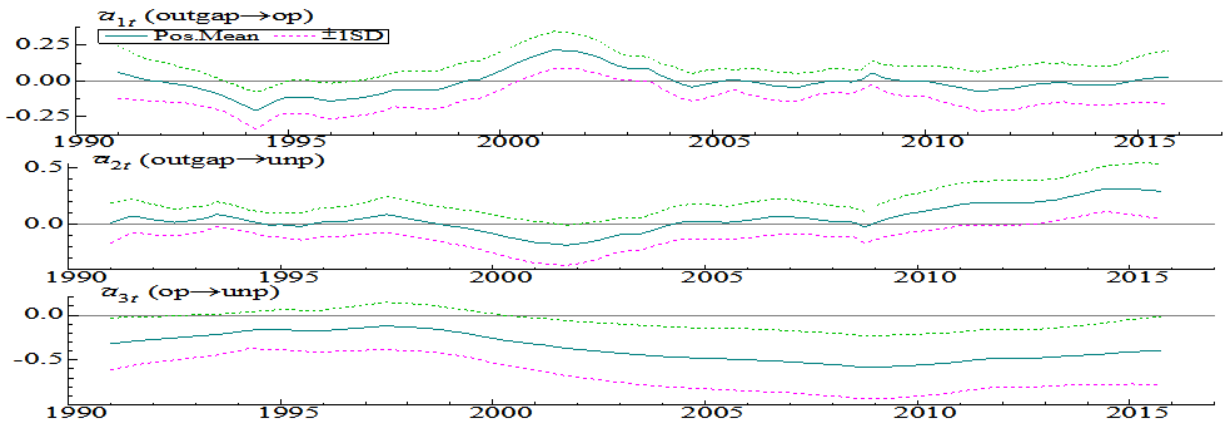


Şekil: 26

\section{Stokastik Oynaklıkların Sonsal Tahmini}
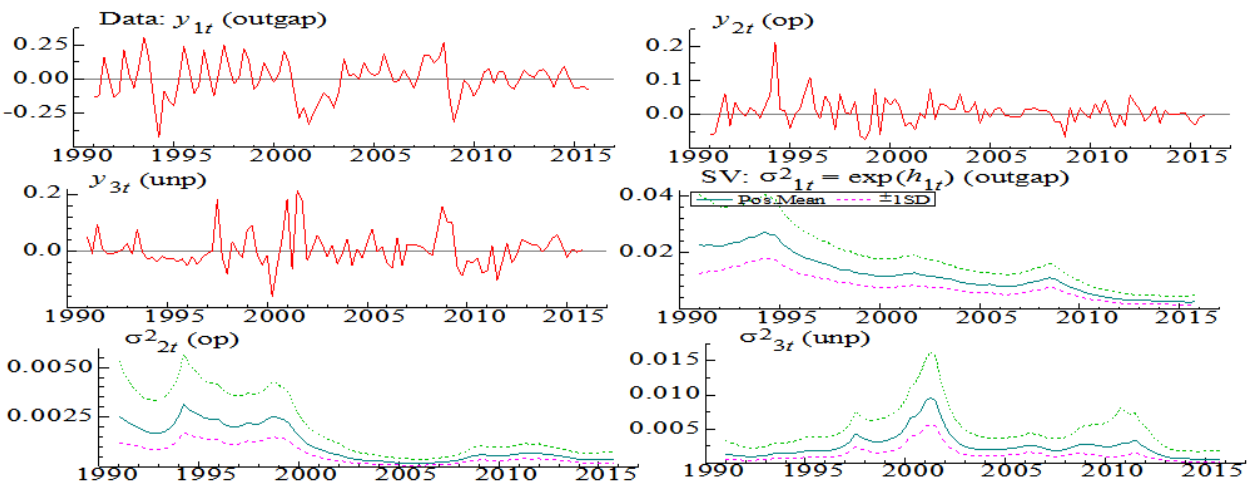

Şekil: 27

TVP-VAR Modeli Etki-Tepki Fonksiyonları

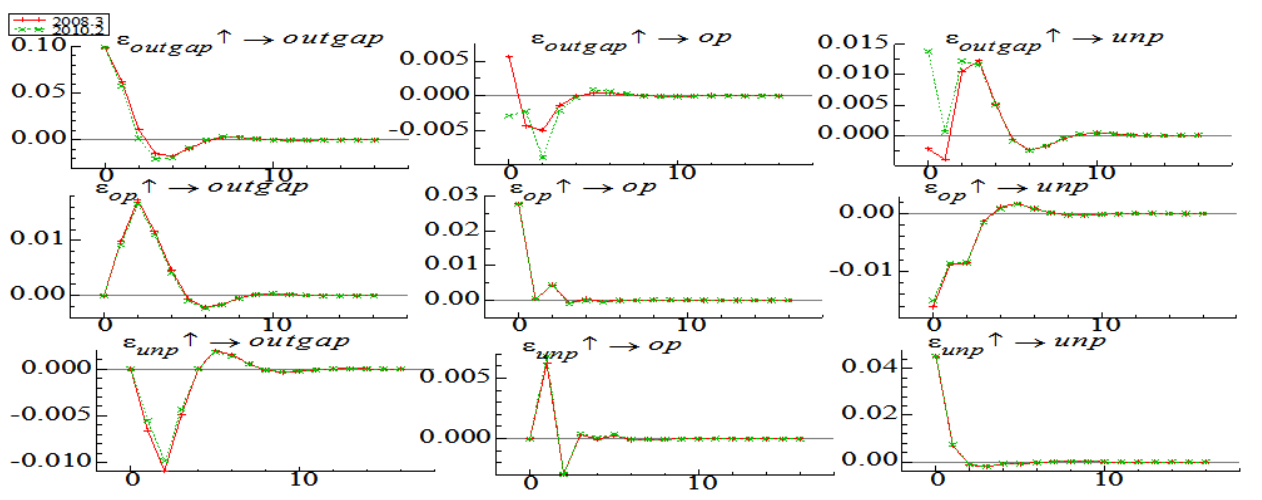

Çalışmada öncelikle TVP-VAR modeli parametre tahmin sonuçları yer almaktadır. Tabloda ortalama, standart sapma, \%5 güven aralıkları, Geweke (1992) yakınsama tanı istatistiği $(C D)$ ve eldeki verilerin son değerleriyle elde edilen tahminler için etkisizlik faktörü bulgusu yer almaktadır. Elde edilen sonuçlara göre Fransa, Almanya, İtalya, İspanya ve Türkiye için verilerin en son değerlerine dayalı dağılımıyla (sonsal dağılım); ulaşılan Geweke yakınsama (CD) değerine göre, parametrelerin dağılımının söz konusu dağılıma uygun olduğunu belirten boş kabul edilmiştir. Dolayısıyla tahminlerin sonsal dağılıma yakınsadığı hipotezi kabul edilmektedir. Bu hipotez İngiltere için reddedilmektedir. Etkinsizlik faktörleri ise ele alınan tüm ülkeler için genellikle 100'ün altında bulunmuştur. $\mathrm{Bu}$ durum elde edilen değerlerin küçük dolayısıyla parametre tahminleri için etkin bir örneklemenin yapıldığını ifade etmektedir. Ayrıca parametre ortalamalarının \%5 güven aralıklarının arasında yer alması ise elde edilen katsayı tahminlerinin güvenilir olduğunu ifade etmektedir. 
Diğer taraftan ele alınan ülkelere ait otokorelasyon, örneklem patikaları ve tahminde kullanılan en son verilerin yoğunluk fonksiyonun (Nakajima, 2011) şekilleri görülmektedir. Örneklem otokorelasyon fonksiyonlarının hızlı bir şekilde düştüğü ve durağan kaldığ1, ayrıca patikasının 10,000 örneklemeden sonra istikrarlı bir yapıya sahip olduğu görülmektedir. Bu durum hata terimlerinin arasında bir ilişki olmadan örneklemler üzerinde etkin bir örneklemenin oluşturulduğunu göstermektedir.

Ülkelere ait yapısal şokların stokastik oynaklıklarını ifade eden şekillerde ise düz çizgiler çıktı açığı $\left(a_{1 t}\right)$, dışa açıklık $\left(a_{2 t}\right)$ ve işsizlik oranlarındaki ( $\left.a_{3 t}\right)$ yapısal şokların ortalamalarını göstermektedir. Kesikli çizgiler ise bir standart sapmalık şokun sınırı temsil etmektedir. Elde edilen sonuçlar incelendiğinde, AB ülkelerinin genellikle işsizlik oranlarında zamana bağlı olarak belli dönemlerde artış ve azalışlar dikkat çekmektedir. Özellikle 2008 kriz döneminde şokların stokastik oynaklığında artış görülürken izleyen dönemlerde işsizlikte bir azalış görülmektedir. Bu durum bir yapısal değişim olmakla birlikte, söz konusu işsizlik oranlarının yapısal bir özellik kazandığının bulgusudur. Türkiye'de ise 2008 krizine göre 1994 ve 2001 krizlerinde şokların stokastik oynaklıkları daha yüksektir. Bunun anlamı Türkiye 2008 krizinden sonra ortaya çıkan şokların etkisini daha hızlı bir şekilde azaltmıştır. 2006 ve 2010 dönemleri sonrası ise şokların kısmen istikrarlı bir seyir izlediği görülmektedir. Bunda ise 2006 ve 2010 yıllarında uygulanan enflasyon hedeflemesi ve yeni para politikası çıkış stratejilerinin önemli etkisinin olduğu ifade edilebilir.

Eşanlı ilişkilerin sonsal tahminini içeren şekiller incelendiğinde, Fransa'da bir standart sapmalık bir dışa açıklık şokunun işsizlik oranı üzerindeki eşanlı etkisi negatif ve zamanla nispeten bir azalış seyri izlemektedir. Almanya'da dişa açıklık şokunun işsizlik oranları üzerindeki eşanlı etkisi 2003'e kadar negatif ve düz 2003'ten sonra ise pozitif ve artan bir seyir izlemektedir. İtalya'da dişa açıklık şoku 2006'ya kadar düz, 2006 da nispeten artan sonrasında ise yine negatif ve giderek azalan bir seyir izlemektedir. İspanya'da ise 2009'da kadar dışa açıklık şoku karşısında negatif ve giderek azalan bir işsizlik oranı görülürken 2009 sonrasında ise negatif ve artan bir seyir izlemektedir. İngiltere'de katsayılar ele alınan dönemde sonsal dağılıma yakınsamadığı için parametreler için etkin bir örnekleme yapılamamış dolayısıyla sonsal dağılımlarla ilgili parametre sonuçları yorumlanmamıştır. Ancak bunun nedeni İngiltere'nin ele alınan ülkelerle aynı konjonktüre sahip olmaması olduğu düşünülmektedir. Nitekim İngiltere'nin ABD'nin ekonomik konjonktürü ile hareket ettiği kabul edilmektedir. Türkiye'de ise 1996 yılından itibaren dişa açıklık şokunun işsizlik oranları üzerinde negatif ve azaltıcı bir eşanlı etkisinin olduğu görülmektedir. Bu sonuç Gümrük Birliği’nin ekonomi üzerindeki yapısal etkisidir.

Stokastik oynaklıkların sonsal tahminine yönelik elde edilen sonuçlar incelendiğinde, Fransa'nın çıktı açığı, dışa açıklık ve işsizlik oranlarında 2010 ve 2014 dönemi arası dönemde önemli ölçüde değişen varyansın olduğu görülmektedir. Bu durum çıktı açığı, dışa açıklık ve işsizlik oranlarına ait grafiklerden de görülmektedir. 2010 döneminde her üç değişkende de önemli kırılma meydana geldiği ve bu kırılmanın serilerin oynaklığında önemli bir artışa neden olduğu görülmektedir. Almanya'nın dışa açıklık oranlarında 2010- 
2013 yıllarında görülen değişen varyans, işsizlik oranlarında 1996-1998 dönemlerinde görülmektedir. Çıktı açı̆̆ında ise 2000 öncesi ve 2010 sonrası dönemlerde söz konusu oynaklık artışları görülmektedir. İtalya'nın çıktı açığı ve dışa açıklık oranlarında 2010-2013 dönemleri arası, işsizlik oranlarında ise 1996-1998 dönemlerinde oynaklık artışları değişen varyansa yol açmaktadır. İspanya'nın dışa açıklık ve çıktı açıklarının oynaklığında 20102012 dönemleri arasında görülen artış, işsizlik oranlarında 1998 döneminden başlayarak 2014 dönemine kadar devamlı yüksek seyirde devam etmektedir. Türkiye'nin dışa açıklık oranlarındaki oynaklık 1994'teki ani yükselişe rağmen 2000'e kadar hızla düşmüş, 2000 sonrası dönemde ise düşük ve istikrarlı bir seyir izlemiştir. İşsizlik oranlarının oynaklığında ise 2001 döneminde görülen ani yükseliş 2010 dönemine kadar belli bir seyirde devam etmiş 2010'ların sonlarından itibaren aniden düşmüştür. Çıktı açığı oynaklığ1 ise 1994 yüksek olmak şartıyla 2009'a kadar nispeten yüksek takip etmiş 2009 sonrasında ise hızla düşmüştür.

Makro iktisatta değişkenler arasındaki dinamik ilişkilerin analizinde etki-tepki fonksiyonları önemli bir araçtır. Etki-tepki fonksiyonları (IRF) sisteme gelen bir standart sapmalık şok karşısında $t=s+1, \ldots \ldots . ., n$ dönem tepkiyi vermektedir. $\mathrm{Bu}$ çalışmada katsayılar zamana göre değiştiği için etki-tepki fonksiyonları da zamanla değişmektedir. Yani ele alınan zaman döneminin her noktasında farklı bir etki-tepki fonksiyonu hesaplanmaktadır. Klasik VAR yönteminde ise ele alınan döneme ait ortalama bir etki-tepki fonksiyonu elde edilmektedir. Diğer bir ifadeyle bir standart sapmalık şoka değişkenlerin verdiği ortalama tepkiler ile bunun etkisinin kalktığı zaman aralığı verilmektedir.

Elde edilen etki-tepki fonksiyonlarına göre, Fransa'nın dışa açıklık oranlarındaki 1 standart sapmalık pozitif şok yaklaşık 10 dönem işsizlik oranlarını arttırdıktan sonra nispeten azalmaya başlamaktadır. Ayrıca 2008 krizi ve Avrupa Borç krizi dönemlerinde de işsizlik oranlarının verdiği tepki değişmemektedir. Çıktı açığındaki pozitif bir şok ise işsizlik oranlarını düşürmektedir. İşsizlik oranlarındaki pozitif bir şokun dışa açıklık oranları üzerinde ise anlamlı bir etkisi bulunamamıştır.

Almanya'da dışa açıklık oranlarındaki bir standart sapmalık pozitif bir dışa açıklık şoku işsizlik oranlarını ikinci ve dördüncü dönemler dışında düşürmektedir. Etki-tepki fonksiyonlarındaki zamana bağlı değişim dikkate alındığında Avrupa Borç Krizi dönemindeki işsizlik oranlarının tepkisinin küresel kriz dönemiyle benzer olmakla birlikte, borç krizi döneminde işsizlik oranlarının daha düksek düzeylerde tepki verdiği görülmektedir. İşsizlik oranlarından kaynaklanan bir şokun dişa açıklık oranları üzerindeki etkisi ise anlamsızdır. Çıktı açı̆̆ından kaynaklanan pozitif bir şok ise yaklaşık 8 dönem işsizlik oranlarını arttırmakta, daha sonra azaltmaktadır.

İtalya'da dışa açıklık oranlarındaki pozitif bir şoka işsizlik oranları birinci döneme kadar azalarak tepki verirken birinci dönemden sonra sekizinci döneme kadar artarak tepki vermekte daha sonra ise tepki sona ermektedir. İşsizlik oranlarından kaynaklanan bir şokun dışa açıklık üzerindeki etkisi ise belirsizdir. Çıktı açığındaki pozitif bir şok işsizlik oranlarını sekiz dönem arttırmakta daha sonra ise azaltmaktadır. 
İspanya'da ise dışa açıklık oranlarındaki bir standart sapmalık pozitif bir şoka işsizlik oranları pozitif tepki verirken, beşinci döneme kadar küresel krizle borç krizinin dönemlerinde verilen tepkiler benzerken beşinci dönemden sonra küresel krizle borç krizi dönemleri birbirinden ayrışmakta ve küresel kriz döneminde işsizlik oranları artmaya devam ederken borç krizi döneminde tepki sona ermektedir. Diğer bir ifadeyle iki dönem arasında asimetrik bir etki oluşmaktadır. Çıktı açığındaki pozitif bir şok yine beşinci dönemden sonra işsizlik oranları üzerinde asimetrik bir etki doğurmaktadır.

İngiltere'nin dışa açıklık oranlarındaki pozitif bir şok işsizlik oranları üzerinde dalgalı bir etki yaratmaktadır. Çıktı açığındaki bir şoka karşı işsizlik oranları yaklaşık sekiz dönem pozitif tepki verirken sekizinci dönemden sonra ise azalan yönde tepki vermektedir.

Türkiye'de dışa açıklık oranlarındaki pozitif bir şok karşısında işsizlik oranları yaklaşık beş dönem pozitif tepki verirken, beş dönem sonra kısmen düştükten sonra durağanlaşmaktadır. Küresel kriz ve yeni para politikasına geçiş stratejileri dönemlerinde ise bu eğilim değişmeden benzer şekilde devam etmiştir. Çıktı açı̆̆ındaki pozitif bir şok yeni para politikası geçiş stratejisi döneminde yaklaşık yarım dönem işsizlik oranları üzerinde daha derin bir düşüşe yol açarken (asimetrik etki) birinci dönemden sonra her iki dönemde de işsizlik oranları benzer tepkiler vermeye başlamıştır. İşsizlik oranlarının ise dışa açıklık oranları üzerindeki etkisi belirsizdir.

\section{Sonuç}

Bu çalışmada işsizlik oranlarıyla dışa açıklık oranları arasındaki ilişki Türkiye ve AB ülkeleri için TVP-VAR yaklaşımı ile incelenmiştir. TVP-VAR yaklaşımı yapısal şokların ve varyans-kovaryans matrisinin zamana bağlı olarak değişimi dikkate alan bir yaklaşımdır. Ayrıca stokastik oynaklık yaklaşımı kullanılarak katsayılardaki geçici ve kalıcı kaymalarla birlikte doğrusal olmayan yapıda analize dâhil edilebilmektedir. Stokastik oynaklığa dayalı olarak zamana göre değişen katsayıların hesaplanmasında ise maksimum olabilirlik yaklaşımından daha etkin olan Bayesgil tahmin yöntemi kullanılmıştır. Simülasyona dayalı katsayılara ait sonsal dağılımların elde edilmesinde ise Gibbs örnekleme algoriması kullanılmıştır.

Elde edilen sonuçlara göre gerek Türkiye gerekse AB ekonomisi açısından özellikler kriz dönemlerinde değişkenlerin stokastik oynaklıklarının arttığı görülmektedir. Bir standart sapmalık dışa açıklık şokunun işsizlik oranları üzerindeki eşanlı etkisi $\mathrm{AB}$ ülkeleri için genellikle artış ve azalış yönünde olurken, Türkiye için 1996 yılından sonra azalış yönünde olmaktadır. 1996 yılında Türkiye'nin Gümrük Birliğine girmiş olduğu dikkate alındığında bu etkinin bir yapısal kırılmaya yol açtığı görülmüştür. Bununla birlikte 1996 yılından sonra dışa açıklık üzerinde pozitif etkisi olan şokların işsizliği doğrudan azaltıcı etkisi olduğu bulunmuştur. Bu açıdan ihracat artışına yol açabilecek gelişmelerin işsizliği azaltıcı olacağı söylenebilir.

Etki- tepki fonksiyonlarına göre, Fransa'da dışa açıklık oranlarından kaynaklanan pozitif bir şok işsizlik oranlarını arttırırken, Almanya'da ise pozitif bir şok işsizlik oranlarını 
düşürmektedir. İtalya'da pozitif dışa açıklık şoku karşısında işsizlik oranları birinci döneme kadar azalırken birinci dönemden sonra artmaktadır. İspanya'da işsizlik oranları dışa açıklığa dayalı pozitif şok karşısında artmaktadır. Ancak beş dönem sonra işsizlik oranları Avrupa borç krizi ve küresel kriz dönemlerine asimetrik bir tepki vermektedir. İspanya da küresel ve Borç krizi döneminde işsizlik oranlarında farklılaşma olmaktadır. İngiltere'de oldukça dalgalı bir seyir izleyen işsizlik oranları, Türkiye'de pozitif bir dışa açıklık şoku karşısında beş döneme kadar pozitif tepki verirken beşinci dönemden sonra tepki sona ermektedir.

Bu çalışmanın en önemli sonucu ele alınan ülkelerin dışa açıklığının işsizlik üzerinde belirleyici bir özellik kazandığını göstermesidir. Bununla birlikte İngiltere için elde edilen sonuçlar açısından, İngiltere ele alınan ülkelerden ayrışmıştır. Bunun anlamı İngiltere'nin ekonomik açıdan AB'den farklılaştığıdır. Fransa ve Almanya için dışa açıklığın etkileri asimetriktir.

\section{Kaynaklar}

Acar, S. (2012), Uluslararası Reel Ticaret: Teori, Politika, İzmir: Dokuz Eylül Üniversitesi Yayınları.

Benati, L. \& H. Mumtaz (2005), "The great stability in the U.K.”: Good policy or good luck?, Mimeo: Bank of England.

Canova, F. (1993), "Modelling and forecasting exchange rates with a Bayesian time-varying coefficient model", Journal of Economic Dynamics and Control, 17, 233-261.

Canova, F. \& L. Gambetti (2009), "Structural changes in the US economy: Is there a role for monetary policy?", Journal of Economic Dynamics And Control, 33, 477-490; doi: 10.1016/j.jedc.2008.05.010

Canova, F. \& F. Ferroni \& C. Matthes (2015), “Approximating Time Varying Structural Models with Time Invariant Structures", Federal Reserve Bank of Richmond Working Paper, 1510 (September).

Carter, C.K. \& R. Kohn (1994), “On Gibbs sampling for state space models”, Biometrika, 81, 541553; http://dx.doi.org/10.1093/biomet/81.3.541

Cogley, T. \& T. Sargent (2005), "Drifts and volatilities: monetary policies and outcomes in the post WWII U.S.”, Review of Economic Dynamics, 8, 262-302.

Del Negro, M. \& G.E. Primiceri (2015), “Time-varying structural vector autoregressions and monetary policy: a corrigendum", Review of Economic Studies, doi: 10.1093/restud/rdv024

Dutt, P. \& D. Mitra \& P. Ranjan (2009), "International trade and unemployment: Theory and crossnational evidence", Journal of International Economics, 7832-44; doi: 10.1016/j.jinteco.2009.02.005

Gozgor, G. (2014), “The impact of trade openness on the unemployment rate in G7 countries", Journal of International Trade \& Economic Development, 23(7), 1018-1037; doi: 10.1080/09638199.2013.827233

Hasan, R. \& D. Mitra \& P. Ranjan \& R.N. Ahsan (2012), “Trade liberalization and unemployment: Theory and evidence from India", Journal of Development Economics, 97(2), 269-280; doi: 10.1016/j.jdeveco.2011.04.002 
Kim, J. (2011), “The Effects of Trade on Unemployment: Evidence from 20 OECD Countries", Stockholm University, Department of Economics Research Papers in Economics, nr. 2011:19, <http://www2.ne.su.se/paper/wp11_19.pdf>, 18.08.2016.

Koop, G. (2003), Bayesian econometrics, Hemel Hempstead: Wiley-Inter science.

Koop, G. \& D. Korobilis (2010), "Bayesian multivariate time series methods for empirical macroeconomics", Foundations and Trends in Econometrics, 267-358.

Koop, G. \& R. Leon-Gonzalez \& R. Strachan (2009), "On the evolution of the monetary policy transmission mechanism”, Journal of Economic Dynamics and Control, 33, 997-1017; http://dx.doi.org/10.1016/j.jedc.2008.11.003

Korobilis, D. (2013), "VAR forecasting using Bayesian variable selection", Journal of Applied Econometrics, 28(2), 204-230.

Nakajima, J. (2011), "Time-varying parameter var model with tochastic volatility: An overview of methodology and empirical applications", Bank of Japan: Monetary and Economic Studies.

Nwaka, I. \& G. Tuna \& K. Uma (2015), “Trade openness and unemployment: Empirical evidence for Nigeria", Economic and Labour Relations Review, 26(1), 117-136; doi: $10.1177 / 1035304615571225$

Ocampo, J.A. \& L. Taylor (1998), “Trade Liberalisation in Developing Economies: Modest Benefits but Problems with Productivity Growth, Macro Prices, and Income Distribution", The Economic Journal, 450, 15-23.

Peluffo Geronazzo, S.A. (2016), "Increased trade openness, productivity, employment and wages: a difference-in-differences approach”, Estudios Regionales En Economía, Población Y Desarrollo, 32, 1-34.

Primiceri, G.E. (2005), "Time varying structural vector autoregressions and monetary policy", Review of Economic Studies, 72, 821-852; http://dx.doi.org/10.1111/roes.2005.72.issue-3

Sandalcılar, A.T. \& N.İ.T. Yalman (2012), “Türkiye'de dış ticaretteki serbestleşmenin işgücü piyasaları üzerindeki etkileri”, Eskişehir Osmangazi Üniversitesi İktisadi ve İdari Bilimler Dergisi, 7(2), 49.

Sims, C.A. (1993), Business cycle, indicator and forecasting (pp. 179-204), Chicago, IL: University of Chicago press for the NBER, Stockholm: Department of Economics, Stockholm University.

Yanıkkaya, H. (2013), "Is trade liberalization a solution to the unemployment problem?", Portuguese Economic Journal, 12(1), 57-85; doi:10.1007/s10258-013-0088-9

Ek Tablo: 1

ADF Birim Kök Testi Sonuçları

\begin{tabular}{|l|c|c|c|c|c|c|}
\hline \multirow{2}{*}{ Ülkeler } & \multicolumn{2}{|c|}{ outgap } & \multicolumn{2}{c|}{ op } & \multicolumn{2}{c|}{ unp } \\
\cline { 2 - 7 } & Ortalama & Trendli & Ortalama & Trendli & Ortalama & Trendli \\
\hline Fransa & $-4.752^{* * * *(2)}$ & $-4.723^{* * *}(2)$ & $-0.964(1)$ & $-2.646(1)$ & $-1.956(1)$ & $-1.882(1)$ \\
\hline Almanya & $-3.762^{* * *}(1)$ & $-3.762^{* *}(1)$ & $-0.250(1)$ & $-3.112(1)$ & $-1.146(3)$ & $-2.002(3)$ \\
\hline İtalya & $-4.708^{* * *(1)}$ & $-4.684^{* * *}(1)$ & $-1.201(1)$ & $-3.176 *(1)$ & $-1.871(3)$ & $-1.754(3)$ \\
\hline İspanya & $-3.441^{* *(5)}(5)$ & $-3.403^{* *}(6)$ & $-1.850(0)$ & $-2.337(1)$ & $-1.977(1)$ & $-2.258(1)$ \\
\hline İngiltere & $-4.427 * * *(1)$ & $-4.400^{* * *}(1)$ & $-1.900(0)$ & $-2.168(0)$ & $-3.062^{* *}(2)$ & $-2.342(1)$ \\
\hline Türkiye & $-2.963^{* *}(9)$ & $-3.705^{* *}(6)$ & $-2.304(4)$ & $-1.964(4)$ & $-1.727(5)$ & $-2.899(5)$ \\
\hline
\end{tabular}

Not: Parantez içindeki değerler Akaike Bilgi Kriterine (AIC) göre belirlenen optimal gecikme uzunluklarıdır.

$* * *, * *, *$ sirasiyla $\% 1, \% 5$ ve $\% 10$ önem düzeylerini ifade etmektedir. 
Ekinci, R. \& O. Tüzün \& F. Ceylan \& H. Kahyaoğlu (2017), "Dışa Açıklık ile İşsizlik Arasındaki İlişsi: Seçilmiş AB Ülkeleri ve Türkiye Üzerine Zamana Göre Değișen Parametreli Bir Analiz”, Sosyoekonomi, Vol. 25(31), 45-73. 